\title{
Where the Earth Breathes Inside: The Attitudes of Lakota People Toward Wind Cave National Park
}

Adam Rossi

Follow this and additional works at: https://researchrepository.wvu.edu/etd

\section{Recommended Citation}

Rossi, Adam, "Where the Earth Breathes Inside: The Attitudes of Lakota People Toward Wind Cave National Park" (2017). Graduate Theses, Dissertations, and Problem Reports. 6533.

https://researchrepository.wvu.edu/etd/6533

This Thesis is protected by copyright and/or related rights. It has been brought to you by the The Research Repository @ WVU with permission from the rights-holder(s). You are free to use this Thesis in any way that is permitted by the copyright and related rights legislation that applies to your use. For other uses you must obtain permission from the rights-holder(s) directly, unless additional rights are indicated by a Creative Commons license in the record and/ or on the work itself. This Thesis has been accepted for inclusion in WVU Graduate Theses, Dissertations, and Problem Reports collection by an authorized administrator of The Research Repository @ WVU. For more information, please contact researchrepository@mail.wvu.edu. 


\title{
Where the Earth Breathes Inside: The Attitudes of Lakota People Toward Wind Cave National Park
}

\author{
Adam Rossi
}

Thesis submitted

to the Davis College of Agriculture, Natural Resources and Design

at West Virginia University

in partial fulfillment of the requirements for the degree of

Master of Science in

Recreation, Parks, and Tourism Resources

\author{
David Smaldone, Ph.D., Chair \\ Steve Selin, Ph.D. \\ Chad Pierskalla, Ph.D. \\ Division of Forestry and Natural Resources \\ Recreation, Parks, and Tourism Resources Program
}

Morgantown, WV

2017

Keywords: Attitudes, indigenous peoples, protected areas, federal agencies, contested land, interpretation

Copyright 2017 Adam Rossi 


\title{
ABSTRACT \\ Where the Earth Breathes Inside: The Attitudes of Lakota People Toward Wind Cave National Park
}

\begin{abstract}
Adam Rossi
Wind Cave National Park, located in the Black Hills of South Dakota, has a long and complex history concerning local indigenous peoples, including the Lakotas. Wind Cave is the location of the Lakotas' traditional origin story, and is now protected by a park that represents a federal government that many indigenous peoples of this country view negatively. Despite this, no study has attempted to characterize attitudes of local indigenous people towards the park. Recommendations from an earlier study encourage the park to collaborate closely with local indigenous tribes, and it would be beneficial for the park to have an understanding of the attitudes of these people. The purpose of this study is to begin to characterize the attitudes of Lakotas toward Wind Cave National Park. Seventeen interviews were conducted with Lakota people to better understand their thoughts and feelings about the park. The transcripts of these interviews were content analyzed, and several themes emerged. Negative themes included lack of Lakota perspectives in park interpretation, fees for cave tours, the tourist attraction nature of Wind Cave, and violation of a historic treaty. Positive themes included preservation, openness about non-indigenous tourists entering Wind Cave, and improvement in interpretation. Younger interviewees generally spoke more favorably of the park than older interviewees. The major finding is that the park needs to include more Native voice in its interpretation. Suggestions for accomplishing this include incorporating more cultural perspectives on cave tours and in Visitor Center exhibits, hiring more indigenous staff members, and inviting tribal members to the park for guest presentations. The park should work closely with Lakota and other local tribes, and can follow the example of other National Park Service sites to accomplish these changes.
\end{abstract}




\section{Table of Contents}

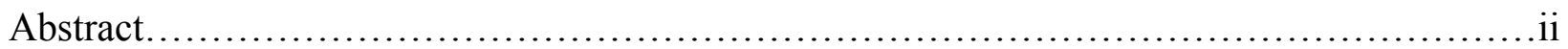

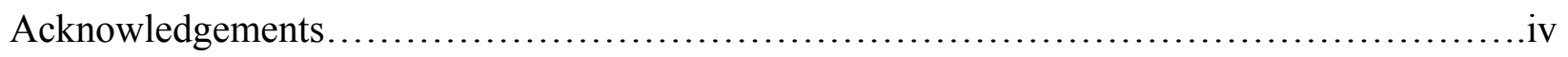

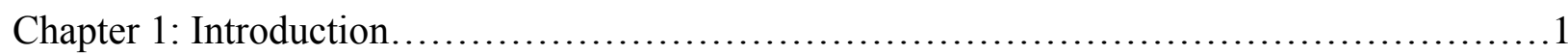

The Lakota People and the Black Hills..........................................

Wind Cave National Park.................................................4

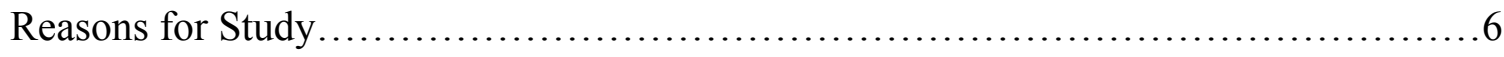

Research Questions.......................................................8

Chapter 2: Literature Review....................................................9

Attitudes/Perceptions of Indigenous Peoples towards National Parks/Protected Areas.....9

Global............................................................

Nepal...........................................................12

Africa............................................................ 15

North and South America.............................................. 16

Latin America......................................................... 17

Canada........................................................... 19

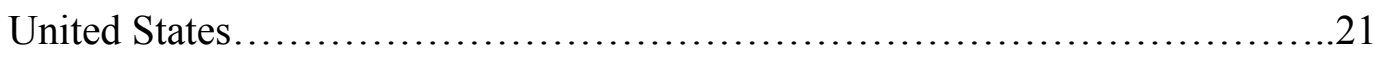

United States Federal Laws/Policies Related to Indigenous Peoples..................29

Life on a Reservation.................................................... 32

Interpretation and Its Relevance to Wind Cave and Lakota Relations..................34

Chapter 3: Methods............................................................ 38

Chapter $4:$ Results...........................................................44

Research Question \#1: What are the attitudes of Lakota people toward Wind Cave 
National Park?

Research Question \#2: What are the attitudes of Lakota people toward the National Park

Service's interpretation of Wind Cave?....

Research Question \#2a: What are the attitudes of Lakota people towards the National

Park Service's personal interpretation of Wind Cave, i.e. a cave tour?

Research Question \#2b: What are the attitudes of Lakota people towards the National

Park Service's non-personal interpretation of Wind Cave, i.e. exhibits in the Visitor Center?....50

Research Question \#3: What are the attitudes of Lakota people toward non-indigenous

people entering Wind Cave?

Research Question \#4: Do the above attitudes differ depending on age?

Other Codes.

Significance of Wind Cave................................................ 56

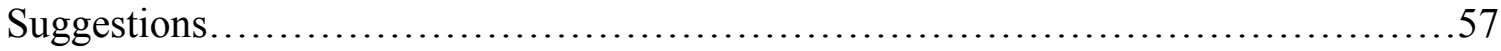

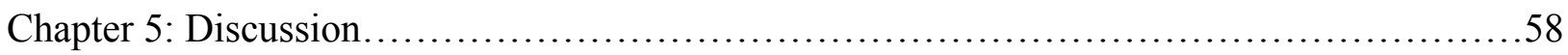

Complex Attitudes.......................................................58

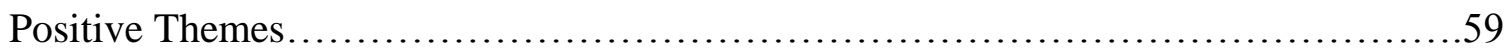

Preservation.......................................................59

Positive Change........................................................60

Entrance Attitudes.................................................60

Negative Themes........................................................63

Lakota Neglect.................................................63

Tourist Attraction....................................................64

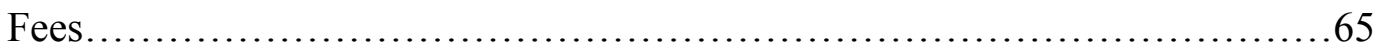


Treaty Violation.......................................................

Differences Based on Age.....................................................67

Recommendations and Implications.......................................67

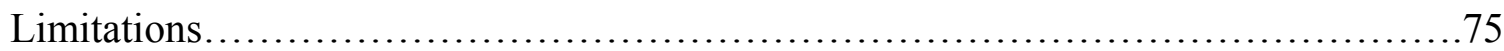

Conclusion.............................................................. 76

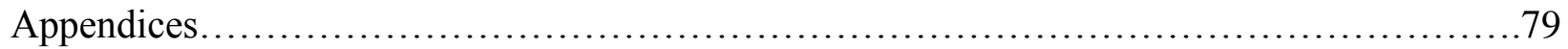

Appendix A: Interview Instrument.......................................... 79

Appendix B: a priori Coding Table............................................ 81

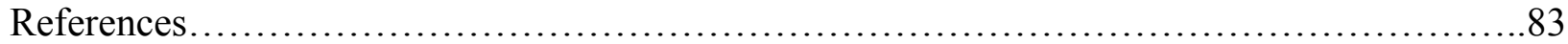




\section{Acknowledgements}

Many, many people helped me complete this study, and to all of them I owe gratitude. However, a specific few deserve special mention.

First of all, thank you to the staff at Wind Cave National Park for allowing me to complete a study that will hopefully be of use. Of particular help were Tom Ferrell and Ted Firkins. Wind Cave will always have a special place in my heart. Thanks also to Sina Bear Eagle for the inspiration for this study and for all of her help throughout the process of completing it.

I would like to thank all those who agreed to be interviewed for this study. Your contributions are sincerely appreciated, and this study obviously would not have been possible had you not been so generous with your time and knowledge.

Dr. Jace DeCory at Black Hills State University was also a tremendous help when it came to finding resources and gaining a more complete understanding of Lakota cultural perspectives. Thanks for being so generous with your time.

Thank you to Julie Brazell and the staff at Custer State Park for giving me the opportunity to work near my study area. Custer State Park, like Wind Cave, will always hold a near and dear place in my heart.

And finally, thank you to all my professors and fellow students at West Virginia University. I've had an incredible experience during my time in Morgantown, and it's because of the wonderful people I've met there. Thanks especially to the members of my committee, Dr. Chad Pierskalla and Dr. Steve Selin; your time spent improving this report is greatly appreciated. And finally, thank you to my major advisor, Dr. Dave Smaldone. I can't thank you enough for all your time, hard work, and enthusiasm that you have offered me over the last two years. You are the best advisor a student could ask for. 


\section{Chapter 1: Introduction}

Wind Cave National Park is located in the southern Black Hills, in the southwestern corner of South Dakota. The park is named for the cave that lies underneath the mixed-grass prairie landscape, one of the longest in the world (R. Horrocks, personal communication, September 14, 2015). There are 21 indigenous tribes that have significant cultural or religious ties to the cave, including the seven bands of the Lakotas (T. Farrell, pers. comm., May 19, 2015). All 21 of these tribes now have reservations away from the cave, which, as part of the park, is under the jurisdiction of the National Park Service (NPS), part of the Department of the Interior of the United States federal government. The complicated history of the cave and the people who have become a part of its story create the potential for varying attitudes among many people, but particularly among the indigenous people who were forced off the land that was once theirs until the 1870s. The purpose of this research is to better understand the attitudes that members of the Oglala Lakota people hold towards Wind Cave National Park. A better understanding of these attitudes is fundamental for the NPS to foster the greatest possible amount of cooperation with, respect for, and inclusion of the aforementioned 21 tribes in park management, planning, and interpretation.

\section{The Lakota People and the Black Hills}

The Lakota people were the dominant indigenous tribe in the region stretching from the Black Hills to the Missouri River in present-day South Dakota from the 1700s until they encountered conflicts with European settlers moving West and the United States government (Lakota, 2005; Stasiuk, 2012). In spite of the Fort Laramie Treaty of 1866, under which the United States government granted to the Lakota people all lands lying west of the Missouri River in the present-day State of South Dakota, the Lakota people were systematically assigned to 
reservations by the government in the late 1800s following the discovery of gold in the Black Hills in 1877 (Reinhardt, 2015).

Many Lakota people maintain that they have viewed the Black Hills as sacred land for many generations (Means, 1996; Sundstrom, 1996; LaVelle, 2001; Afraid of Bear-Cook, 2009; Reinhardt, 2015). Such a view among an indigenous culture is hardly unique; many indigenous cultures are tied closely to the land where the people live, and often that land has sacred or spiritual significance (International Labor Organization, 2003; Rights and Resources Initiative, 2015). Worster (1992), however, contests the special significance of the Black Hills to the Lakotas, asserting that although the Lakotas view all land as sacred, there is no evidence that they viewed the Black Hills as being more sacred than any other land until the 1970s, when legal battles raged over the ownership of the Black Hills. The Lakotas had long maintained that the Hills were illegally seized by the government in 1877 , a claim that was finally upheld by the United States Court of Claims in 1979 in Sioux Nation of Indians v. United States (1979). The Lakotas were awarded $\$ 106$ million at the time, but declined to accept the money, insisting that it was not the money they wanted, but the land itself (United States v. Sioux Nation of Indians, 1980; Worster 1992; Morrison, 2014). As of 2011, the trust fund held about $\$ 1.3$ billion (Winslow, 2011). More recently there have apparently been more Lakota people who call for settling the land claim by accepting the money; a lawsuit in 2009 called for the funds to be distributed among current tribal members, although many tribal members remained staunchly opposed to the suit (Brokaw, 2009). At the time of this writing, the issue has yet to be resolved (S. Bear Eagle, pers. comm., June 14, 2015).

One chapter of the Black Hills land claim battle has particular significance to Wind Cave. In 1985, Senator Bill Bradley (D-NJ) introduced a bill that would have returned 1.3 million acres 
of the Black Hills to the Lakotas, including Wind Cave National Park (Worster, 1992).

According to the bill, the park would have been combined with nearby Jewel Cave National Monument and branded as Sioux National Park (Worster, 1992). After several versions of the bill were killed at several consecutive legislative sessions, in 1989 Senator Bradley did not introduce the bill, apparently abandoning the cause (Worster, 1992).

Morrison (2014) counters Worster, claiming that there is sufficient evidence that the Black Hills are regarded as the spiritual center of the universe. For example, tribes were required to go to specific sites in the Black Hills at certain times of the year for ceremonies (Morrison, 2014). A "Lakota Star Project" conducted by Sinte Gleska University on the Rosebud Sioux Indian Reservation found evidence for an ancient, sacred relationship between the Lakota, the Heavens, and the Black Hills (Morrison, 2014). Pe Sla Paha, a high-altitude meadow, is specifically regarded by many Lakotas as the center of the universe (Cook, 2014).

Pe Sla Paha (Bald Top Mountain) is just one of many sacred sites located in the Black Hills, or He Sapa. Others include Mato Tipila (Bear Lodge or Devils Tower), Inyan Kaga (Inyan Kara Mountain), Okawita Paha (Gathering Hill or Black Elk Peak, formerly Harney Peak), and Mato Paha (Bear Butte). Pte Ahinape, or Buffalo Gap, is located just outside park boundaries. Part of Ki Inyanka Ocanku, or The Race Track, the Red Valley surrounding the heart of the Black Hills, is located within Wind Cave National Park. And then, of course, there is Wind Cave itself.

Despite Worster's claims concerning the sacredness (or lack thereof) of the Black Hills to the indigenous people of the area and his thorough essay on the subject, the Lakota people do, without question, have reason to believe the cave is of particular cultural significance. According to a Lakota story, human life proceeded from the spirit world to the Earth's surface 
through a portal located deep within Oniya Oshoka, meaning "Where the earth breathes inside" (S. Bear Eagle, pers. comm., May 31, 2015). Oniya Oshoka is understood by many to be located within what has been termed by non-indigenous people "Wind Cave," and is located in the Black Hills (S. Bear Eagle, pers. comm., 5/31/15). (The cave is known by many Lakota names, including Makoce Ohloka, which translates to "Breathing Earth" (S. Bear Eagle, pers. comm., 5/31/15); Wasun Wiconiya Wakan or Washun Niye, meaning “Sacred Wind Breath"; Maka Oniye, meaning "Breath of the Earth"; and Pte Kinapapi, which means "Where the Buffalo Come Out) (J. DeCory, pers. comm., 8/2/16). The Cave has been preserved within the boundaries of Wind Cave National Park since the Park's establishment in 1906 (National Park Service, 2015b).

\section{Wind Cave National Park}

Although known to indigenous tribes in the region (besides the Lakotas, the Arapahos and Cheyennes, among others) for generations, the "rediscovery" of Wind Cave by European Americans is generally credited to two brothers, Jesse and Tom Bingham, who found the natural entrance to the cave while hunting in 1881 (Albers, 2003; NPS, 2015b). Homesteaders eventually developed "Wonderful Wind Cave" as a "show cave" and led tours of the cave throughout the 1890s (Spence, 2011). Feuding over claims to the land on which the natural entrance to the cave is located led to a court battle between two families in the late $1890 \mathrm{~s}$, and the decision was made in 1899 that neither family had a legal claim to the cave (Spence, 2011). In 1901 the land was withdrawn from homesteading, and in 1903, Wind Cave National Park became the United States' eighth national park and the first created to protect a cave (Spence, 2011). 
Besides being significant in Lakota and other indigenous cultures, Wind Cave, the focal point of the national park, is the sixth-longest cave in the world and is often identified as one of, if not the, most complex caves in the world (R. Horrocks, pers. comm., Sept. 14, 15). The cave is best known for its unique boxwork; Wind Cave contains the world's vast majority of this unique web-like calcite formation (NPS, 2015d). Exploration of the cave is ongoing, as cavers continue to discover previously unvisited parts of the cave (R. Horrocks, pers. comm., May 31, 2015).

Today, the Oglala Sioux Tribe is one of several federally-recognized tribes with important historical and cultural relations to the lands of Wind Cave National Park (Albers, 2003). Members of the tribe continue to hunt and procure other resources in the Black Hills surrounding the park (Albers, 2003). Many members (just over half) live on the Pine Ridge Indian Reservation, the Oglala Lakota reservation (South Dakota Department of Tribal Relations, 2011), which is located on the plains and badlands to the east of the Black Hills and Wind Cave National Park; it was established in 1889 (Reinhardt, 2015).

Many national parks have staff that deal primarily with indigenous/park relations. The position of cultural resources program manager (formerly known as cultural resources specialist) of the National Park Service (NPS) exists at a number of NPS parks and other units, and people who fill those positions have wide-ranging job responsibilities (NPS, 2015a). Program managers may also work in support offices or program centers (NPS, 2015a). These positions exist within every organizational level of the NPS (NPS, 2015a). Duties of cultural resource managers could include the following: coordinating or accomplishing activities involving cultural resources management; supervising, leading, or managing cultural resource programs, discipline specialists, or other cultural resources managers; working with a variety of cultural resources 
partnership programs; and planning (NPS, 2015a). Although 21 tribes have ties to Wind Cave National Park and the park deals with many on a regular basis, especially the Lakotas, the position of cultural resources program manager does not exist at Wind Cave National Park (S. Bear Eagle, pers. comm., July 21, 2015). Currently, Park staff typically consult with the tribal president/chairman (both titles are used) and with the Tribal Historic Preservation Officer (T. Farrell, pers. comm., Nov. 6, 2015).

\section{Reasons for Study}

The tumultuous and rocky history of the relationship between the Lakota Nation and the United States government are cause for many strong feelings of both Lakota and non-indigenous people concerning Wind Cave National Park and the Black Hills region in general. Because of this, Albers (2003) recommends that Wind Cave National Park should continuously work to establish positive relations with local tribes, including the Lakotas. Involving these tribes in the development of narratives for interpretive programs and literature is a key way to help build this relationship (Albers, 2003). "Further and direct consultations" (p.647) with tribal authorities are needed for the park to incorporate appropriate cultural elements into its interpretive programming (Albers, 2003).

Park management agencies and indigenous peoples often hold differing attitudes toward land, which often leads to contested terrain (McAvoy et al., 2003). As stated by McAvoy et al. (2003), park management agencies and their personnel need to understand the historical and current aspects of contested terrain. This includes the cultural attachment indigenous peoples have to park lands, their history of dealing with those lands, and the history of dealing with the land management agencies (McAvoy et al., 2003). 
These aspects of contested terrain will have a direct effect on park interpretation. Understanding the attitudes held by local tribes toward the park is fundamental in order to understand what elements of indigenous culture should be included in park interpretation, and how they should be included. Despite the tumultuous history of the relationship between European-Americans and indigenous tribes in the Black Hills, it appears that no prior studies have attempted to formally characterize the attitudes of any of the local tribes towards the park itself. The relationship between the Lakotas and Wind Cave National Park is especially unique; although what many view as the illegal seizure of the Black Hills by the United States government remains a contentious issue to this day, the fact that Wind Cave itself is a site of such prominence and even sacred value to the Lakota people warrants research into identifying attitudes held by the Lakota people towards the park.

This is especially important in the 21 st century, as the National Park Service and other federal agencies are increasingly moving away from a top-down management approach and embracing the movement of "participatory planning" (Steelman, 2001; Burby, 2003; Brown and Weber, 2011). In 2009, the National Park Service published Stronger Together: A Manual on the Principles and Practices of Civic Engagement (Tuxill et al., 2009), which stressed collaborative park planning with key stakeholders and other community members. Clearly, the Lakota people are a people with a significant interest in Wind Cave and, therefore, the park. If the park is to embrace the National Park Service's practices of civil engagement, the Lakota people are a primary, if not the primary, group that needs to be consulted. Having an understanding of the attitudes held by Lakota people before coming to the planning table should be extremely important for the park, and this study will allow the park to gain such an understanding and inform park decision-making. 


\section{Research Questions}

The following research questions have been proposed:

RQ 1: What are the attitudes of Lakota people towards Wind Cave National Park?

RQ 2: What are the attitudes of Lakota people toward the National Park Service's interpretation of Wind Cave?

RQ2a: What are the attitudes of Lakota people towards the National Park Service's personal interpretation of Wind Cave, i.e. a cave tour?

RQ2b: What are the attitudes of Lakota people towards the National Park Service's nonpersonal interpretation of Wind Cave, i.e. exhibits in the visitor center?

RQ 3: What are the attitudes of Lakota people toward non-indigenous people entering Wind Cave?

RQ 4: Do the above attitudes differ depending on age? 


\section{Chapter 2: Literature Review}

The purpose of this literature review is to provide background information about the following concepts: attitudes/perceptions of indigenous peoples towards national parks/protected areas (on both a global scale and in the Americas), American Indian law, life on an Indian reservation, and interpretation and its relevance to Wind Cave National Park and its relationship with Lakota people.

\section{Attitudes/Perceptions of Indigenous Peoples towards National Parks/Protected Areas}

Global. There has been much research conducted on the attitudes of indigenous peoples toward protected areas in a global context; much of this research has occurred in Nepal (Heinen, 1993; Allendorf, 1999; Mehta and Heinen, 2001) and Africa (Infield, 1988; De Boer and Baquete, 1998; Gillingham and Lee, 1999). Most of these studies deal with a group of people who were forced to relocate due to the establishment of a national park (for example, McLane and Straede, 2003). The studies that do not involve relocation deal with people who experienced the establishment of a national park in close proximity to their land (for example, Anthony, 2007).

The prevalence of such studies can be attributed to the fact that there are still many parks today that operate under the "Yellowstone model" of park management (Stevens, 1997). According to Stevens (1997), the Yellowstone model—-"parks in which settlement is prohibited and both subsistence and commercial uses of natural resources are banned"- "has become the world standard" (p.28).

However, one of Stevens' (1997) major themes is, "the Yellowstone model of uninhabited, central government administered wilderness national parks is inappropriate for 
indigenous homelands and must be replaced by other goals and institutional arrangements" (p.6). Beltrán has also challenged the Yellostone model (2000). Some contend that these challenges are due, at least in part, to a focus on human rights reforms (Rights and Resources Initiative, 2015). Whatever the cause, it is being increasingly recognized that indigenous peoples, for a great portion of human history, have modified and shaped the ecosystems they have inhabited (Blackburn and Anderson, 1993; Atleo, 1998). Therefore, the idea of an untrammeled wilderness is likely a myth (McNeely, 1993). Taking into account this increased understanding of the historical relationship between indigenous peoples and the earth, and also recognizing that the Yellowstone model has infringed upon the rights of indigenous people around the globe, there has been an increased number of protected areas that have moved away from the Yellowstone model of management towards various forms of co-management between park staff and indigenous inhabitants (Stevens, 1997; Rights and Resources Initiative, 2015). In some cases, even indigenous management has been explored, a management strategy under which final decision-making authority rests with the indigenous people themselves (Stevens, 1997; Rights and Resources Initiative, 2015). The Yellowstone model, as defined by Stevens, refers to the lack of indigenous habitation and use, and not is not a management strategy per-se (1997). However, it is clear from Stevens' theme (stated above) that in practice, the Yellowstone model involves park management by "central government," and he uses the model throughout the book as a contrast with co-management (1997).

The recent trend towards co-management is reflected in the World Conservation Union's (IUCN) categories of protected areas, which include designations of lands that are compatible with indigenous use and habitation (Stevens, 1997). (It is important to note that the United States' National Park System does not follow the IUCN framework for protected areas (R. 
Burns, pers. comm., September 9, 2015).) The 1992 World Congress on National Parks and Protected Areas called for the development of policies that take into account the interests of indigenous peoples (Beltrán, 2000); and the IUCN and the World Wildlife Fund (WWF) adopted their Principles and Guidelines on Indigenous/Traditional Peoples and Protected Areas in 1999, which has served as a guide for many organizations to develop their own policies regarding their management philosophy as it relates to indigenous peoples (Fernández-Baca and Martin, 2007).

Despite this trend towards more inclusive park policies, many still hold "environmentalist" attitudes that no one, including indigenous people, should be allowed to live within a protected area (Keller \& Turek, 1998). Others hold ill-informed views of indigenous peoples as romantic natives who "live in harmony with the land" (i.e., have no impact on the ecosystem whatsoever) (Keller \& Turek, 1998). As a result, many protected area management systems fall well short of the co-management ideal (Beltrán, 2000), and there continue to be many protected areas around the world that operate under the Yellowstone model of restricted human impact and permit very little use (Stevens, 1997; Beltrán, 2000).

Kakadu National Park in Australia presents an interesting case illustrative of the preceding discussion. Following its establishment in 1979, the park has successfully implemented a co-management approach under which the Aborigine people play a very active role in park management (Stevens, 1997; Beltrán, 2000). Much of the land of the national park is actually owned by the people and leased to the government, and access to many sacred sites of the Aborigine in the park is restricted (Stevens, 1997; Beltrán, 2000).

The aforementioned studies dealing with people who were relocated in order to establish a national park involved parks operating under the Yellowstone model. Many of these studies identify variables (such as level of income, level of education, level of wildlife conflict, land 
ownership, and age) that predict attitudes towards the protected area (either positive or negative). However, most of these variables, if not all of them, are not generalizable across other areas and peoples, and are specific to the particular contexts in which they were studied. For example, Infield (1988) found level of affluence to be a predictor of attitude toward a protected area in South Africa; Heinen (1993), meanwhile, found that socioeconomic status was not a predictor of attitude toward a protected area in Nepal.

Also, it should be noted that most of these studies fail to adequately define "attitude"; many of them also fail to justify their survey/interview questions used to determine attitude. For example, Infield (1988) asked questions about perceptions of certain management practices in order to gauge attitude toward a protected area, without acknowledging the fact that respondents would not necessarily feel the same way about specific management practices and the protected area itself. The exception to this generalization is Allendorf (1999), who used a qualitative approach to characterize the relationship between the local residents of a national park in Nepal and the park itself. In the present study, attitude will be defined as by Eagly and Chaiken (1993): "a psychological tendency that is expressed by evaluating a particular entity with a certain degree of favor or disfavor."

Nepal. The following studies have been grouped by geographic region. The first set of studies took place in Nepal. A largely undeveloped country, Nepal was formed from many small kingdoms and is home to a vast array of indigenous and aboriginal peoples (Prashant, 2014). Since 1973, the Nepalese government has established 20 protected areas, half of which carry the title "national park" (Bhuju et al., 2007).

Heinen (1993) studied park-people relations for two years in Nepal, where he surveyed people living near the Kosi-Tappu Wildlife Reserve. Despite measurable benefits among local 
residents, attitudes toward the reserve were generally poor. Socioeconomic status or direct cost of reserve to respondent were not good predictors of attitude. Heinen suggested that education and societal discrimination influenced the attitudes held towards the protected area.

Allendorf (1999) studied the relationship between local people and three protected areas in Nepal. She identified the positive and negative attributes that local residents associated with the protected areas and put them into historical, political, and social context. More so than in previous studies, Allendorf took great care to define "attitude" and to adopt a psychological framework as the basis for her study. Based on her research findings, she proposed a conceptual framework based on attitude theory to describe the relationship between people and protected areas. In this framework, external variables like socio-economics, demographics, personality traits, and life experiences influence both attitudes toward the area and interactions with the area. The interplay of these attitudes and interactions create the relationship between the person and the place.

Mehta and Heinen (2001) examined whether or not community-based conservation programs improved local attitudes toward two protected areas in Nepal. They also aimed to determine whether or not perceived costs and benefits from the protected area influenced these attitudes. An overwhelming majority of people near both protected areas held favorable attitudes towards the protected area, providing evidence that community-based conservation programs do help create more positive attitudes towards protected areas. The researchers identified a number of predictors for positive attitudes for one or both protected areas: participation in skills training, benefit from tourism, low human/wildlife conflict, and a higher level of education. In addition, men were more likely to hold favorable attitudes than women for one of the protected areas, and 
members of certain ethnic groups held more favorable attitudes than others for each protected area.

In a case study of Royal Chitwan National Park in Nepal, McLane and Straede (2003) found that attitudes toward nature conservation and the national park among the local people remained high even after they were forced to relocate off their traditional land for the purpose of creating the park. The finding that positive attitudes were expressed towards the park seems incredible given the fact that almost all the interviewees had experienced some sort of conflict or problem related to the proximity of the park to their land. Conflicts with wildlife were the most common problem. Some interviews identified the fact that resource collection (such as fuelwood) was restricted inside the park as a problem. Another problem identified by the villagers was the inadequate location of the new settlement area (New Padampur) with regards to avoiding wildlife conflicts. Despite the fact that engagement of the local people was not considered in the management process of the park, $83 \%$ of interviewees felt that the establishment of protected areas for the sake of nature conservation was important, and $86 \%$ felt that Royal Chitwan National Park in particular should be kept as a protected area.

Baral and Heinen (2007) compared two protected areas in Nepal, one that had more widespread social and economic interventions for longer time periods, and one that had relatively recent interventions. Survey respondents from the protected area with more social and economic interventions indicated a more favorable attitude towards conservation than those from the other protected areas with fewer interventions. Those who had received skill training for income enhancement, had experienced low levels of wildlife conflict, had a high dependence on resources, and had a high satisfaction with user group activities were more likely to hold favorable conservation attitudes. The authors suggested that a more liberalized view of protected 
area management leads to higher levels of resource use by locals, which in turn improves their livelihoods and results in more positive attitudes towards the protected area.

Africa. Besides the plethora of attitude and protected area studies in Nepal, similar studies were also conducted in Africa, where the Yellowstone model for park management often involved relocation of local people (Stevens, 1997). The following studies take place in South Africa, Mozambique, Tanzania, and Uganda. Each of these countries, located in southern or eastern Africa, has a long and varied history concerning indigenous peoples (Feinstein, 2005; Kanyeihamba, 2010; Funada-Classen, 2013; Mbogoni, 2013).

Infield (1988) studied the attitudes of a rural community in South Africa toward a local conservation area. He found that $65 \%$ of local residents held a positive attitude toward the concept of conservation. However, a lower percentage of respondents thought positively of the conservation area itself or its managers. He also compared the responses across several demographic variables, and found that positive attitudes were correlated with high affluence and high level of education. Also, a positive attitude toward conservation was associated with those households that were most Westernized and least Westernized. Furthermore, those households which had received direct benefits from the conservation area were more likely to support conservation.

De Boer and Baquete (1998) conducted a study aimed at understanding the perceptions of the impacts of the Maputo Elephant Reserve in Mozambique on the local people. Using a combination of interviews and surveys, they estimated the relative value of the natural resources of the reserve in relation to the attitudes towards it. An overwhelming majority (88\%) answered that they "liked" the reserve. People who experienced crop damage from reserve animals were more likely to have negative opinions of the reserve. The researchers also found an inverse 
relationship between the number of species invading a person's agricultural field and his attitude towards the reserve. However, attitudes varied among different study sites within/in close proximity to the reserve.

Gillingham and Lee (1999) surveyed local visitors near a game reserve in Tanzania to gauge their attitudes towards a number of items related to wildlife and the game reserve, including attitudes towards the game reserve itself. They found widespread negative attitudes towards the wildlife management institutions. Gaining direct benefits from wildlife management programs and holding positive attitudes towards wildlife conservation in general apparently had no effect on villagers' attitudes towards the reserve itself.

Infield and Namara (2001) assessed attitudes in order to gauge the success of a community conservation program (CCP) in a Ugandan national park, and found mixed results. People who lived in communities involved with the program had more positive attitudes towards the park than those who were not involved. However, the study failed to find improved attitudes over the seven-year duration of the program. The researchers found that attitudes were influenced by community development assistance, land ownership, and economic occupation.

Anthony studied the attitudes of people living near Kruger National Park in South Africa (2007). Using a 12-question survey, Anthony created an "attitude index" that ranged from -12 (very negative) to +12 (very positive). The average score was just over two; he found a large variation in attitudes among the 240 households included in the study. Positive attitudes were associated with having a family member employed by the park, being younger, and living in a certain jurisdiction. Negative attitudes were associated with damage-causing animals.

North and South America. As has been seen in other regions of the world, there has been a movement in North America towards involving indigenous people in the management of 
protected areas; natural resources conservation and indigenous cultural preservation are increasingly seen as complimentary goals rather than competing ones (Stevens, 1997; FernándezBaca and Martin, 2007). Illustrating this point is the Program of Work on Protected Areas, established by the IUCN; one of its goals is "full and effective participation of indigenous and local communities in the management of existing protected areas and the establishment of new areas in full compliance with their rights and recognition of their responsibilities,..." (FernándezBaca and Martin, 2007, p.2, from Secretariat of the Convention on Biological Diversity, 2004).

Latin America. In Latin America, most countries have management approaches related to protected areas that strive toward two goals: first, to protect natural resources; and second, to satisfy the needs of the local communities that benefit from those natural resources (FernándezBaca and Martin, 2007). However, many indigenous people feel that they are not able to fully benefit from such policies and would prefer autonomous indigenous territories where decisionmaking regarding protected areas rests solely in their hands (Fernández-Baca and Martin, 2007). There has, in fact, been a movement over the last thirty years in Latin America towards setting aside land as indigenous territory; for example, over $12 \%$ of the land territory in Brazil is recognized as indigenous territory (Roldán, 2004).

Many protected areas in South and Central America illustrate the above ideas. In Bolivia, Kaa-Iya National Park is moving towards a co-management approach through the establishment of management committees, an approach dubbed "co-administration" by Winer (2003). These committees, which play a vital role in management decision-making in different areas of the park, are made up of both the park management authority and indigenous peoples living in the area, as well as other stakeholders (Beltrán, 2000). The Cayos Miskitos and Franja Costera Marine Biological Reserve in Nicaragua similarly exhibits an increasing collaborative effort 
between the federal environmental agency and the indigenous people who live in villages along the marine protected area (Beltrán, 2000). Although no studies have been conducted investigating attitudes of the indigenous peoples toward either of these areas, many early indicators in Bolivia, such as the effectiveness of the management strategy from an ecosystem perspective and high attendance at public meetings by indigenous groups, suggest that attitudes are, in general, quite positive (Beltrán, 2000).

A very unique example is provided by Sarstoon-Tamash National Park in Belize. The park was established without any involvement of the indigenous communities living in the region (Beltrán, 2000). In fact, many of those living in the area were unaware of the park's existence; some remained unaware for up to three years after the park's establishment (Beltrán, 2000). Early indicators signaled a very negative attitude toward the park, as leaders of affected communities began a plan to dismantle the park (Beltrán, 2000). However, the community stakeholders decided instead to pursue a co-management relationship with the government agency overseeing the park, and attitude indicators have improved since the government has shown an increased commitment to involving the local people in park management (Beltrán, 2000).

Kaus (1993) conducted research in a biosphere reserve in Mexico. He found that the local attitudes towards an endangered species of tortoise actually changed since the establishment of the preserve. The primary purpose for the establishment of the preserve was protection of the tortoise; it had traditionally been a part of the local peoples' diet, and prior to the designation of the biosphere reserve, the locals sold tortoises in adjacent states in Mexico. However, after the reserve was established, the people not only stopped consuming the tortoise, but they also informed neighbors and visitors of the non-harvesting policy of the tortoise. They 
developed an attitude that approached pride towards the fact that their land was part of a biosphere reserve.

At the same time, attitudes concerning other species in the reserve differed greatly between managers and locals. Local people viewed species such as coyotes and rattlesnakes as pests and had no reservations about illegally shooting such animals. They also had differing views of the vegetation present in the reserve; while managers valued biodiversity of flora, locals tended to see value in plants in terms of their economic or functional value. Likewise, the land itself was viewed differently (Kaus, 1993). Locals described the desert land as being "very tough," a landscape that must be contended with and even overcome in order to survive; managers, on the other hand, viewed the land as a "fragile ecosystem," a landscape that must be protected if it was to survive. The environment, for the managers, was to be understood; for the local people, it was to be used.

Canada. We also see similar themes concerning co-management to the north of the United States. Canada, like the United States, has a long history between European settlers and indigenous peoples (referred to in Canada as "First Nations") (Stevens, 1997; Beltán, 2000; McAvoy et al., 2003). Although some may view Canada's relationship with indigenous peoples as being much more progressive than the United States' (Stevens, 1997), the treatment of indigenous peoples has varied across the country. Nunavut, a territory set aside for the Inuit people, was officially created in 1999 from land formerly belonging to the Northwest Territories. In stark contrast, the government has largely neglected the people of British Columbia since confiscating their lands and suppressing any resistance (Fisher, 1994).

Wood Buffalo National Park is Canada's best example of a park with a long history of indigenous use and involvement (Beltrán, 2000). West (1991) identifies the park as a prime 
example of successful co-management, where management decisions have been made jointly between the government and native peoples. However, co-management has not always been achieved without conflict, and many challenges continue to face the park (Stevens, 1997; Beltrán, 2000; Nishi et al., 2006; UNESCO, 2016). Other protected areas in Canada with a history of indigenous cultural ties have not progressed towards co-management (McAvoy et al., 2003). Little research was found regarding attitudes of indigenous peoples towards Wood Buffalo or other parks.

It should not go without mention, however, that Canada has indeed been relatively progressive in regards to establishing a relationship between Parks Canada and the First Nation peoples of the country, especially when compared to the United States. Parks Canada established its Indigenous Affairs Branch (IAB) in 1999 to help the agency build and foster “meaningful relationships" with indigenous peoples (Parks Canada, 2016). A year later, Canada created the Aboriginal Consultative Committee (ACC), which meets three times a year to provide guidance to Parks Canada (Parks Canada, 2016). The country also instituted the Aboriginal Working Group (AWG), which provides advice to Parks Canada concerning indigenous employment, and the Aboriginal Leadership Development Program (ALDP), which allows for indigenous employees to gather and learn a wide variety of skills (Parks Canada, 2016). But the agency had been working with First Nations peoples well before the establishment of the IAB, ACC, AWG, and ALDP. In 1974, an amendment to the Canada National Parks Act allowed for lands to be set aside as National Park Reserves, which allows for lands to be set aside and managed as national parks while land claim negotiations are resolved (Parks Canada, 2016). The amendment has been an "effective tool for forging strong relationships with indigenous peoples" (Parks Canada, 2016). After 1993, Parks Canada began 
including provisions for cooperative management boards when establishing parks (Parks Canada, 2016). These boards allow for indigenous people to participate in planning and decision-making for the proposed parks (Parks Canada, 2016).

United States. Although lagging far behind its neighbor to the north, the trend towards co-management carries over to the United States as well. The foremost example is Canyon de Chelly National Monument in Arizona. Surprising as it may be to many people, the NPS and the Navajo Nation have jointly managed the Monument since 1931 (Keller \& Turek, 1998). The land in the Park is owned by the Navajos, and about 40 Navajo families live in the Monument (NPS, 2017b). Although the NPS claimed in the 1930s that the Monument demonstrated "how well parks could operate inside Indian reservations," (Keller \& Turek, 1998, p. 212) the relationship between the Park Service and the Navajos was anything but amiable for several decades. By 1958, an NPS investigation of the monument concluded that Navajos distrusted “anything and anyone from Washington” (Keller \& Turek, 1998, p. 210), and for good reason. Numerous NPS regulations created undue intrusions and strains on Navajos living in the canyons, who were already disturbed by tourists visiting the Monument, and the inability of the Park Service to keep climbers off the sacred Spider Rock foreshadowed future controversies at Devils Tower National Monument (Keller \& Turek, 1998). The early relationship between the NPS and the Navajos became so strained that the tribe repeatedly demanded that the Park Service leave (Keller \& Turek, 1998).

But Navajos have also benefitted over the years from the relationship. The Park Service has assisted the Tribe through training programs, tourism development, and even through numerous examples of individual aid (Keller \& Turek, 1998). Park rangers have assisted tribal police, held Easter egg hunts for Navajo youth, killed nuisance wildlife, saved domestic animals 
and pets (and on occasion their owners as well), driven sick Navajos to the hospital, and even assisted in Navajo burials (Keller \& Turek, 1998). Navajo/Park Service relations have improved since the 1970s, and although their bond is far from perfect, the fact that such a cooperation remains in existence in the United States after eighty-five years demonstrates that the concept of joint management is neither implausible nor novel in this country (King, 2007).

An example can even be seen in the Oglala Lakota's joint management, along with the NPS, of the South Unit of Badlands National Park, which is located within the Pine Ridge Reservation. Although the Unit, comprised of two disparate areas, has been managed jointly by the NPS and tribe since 1976, the two groups are reportedly working toward a future of indigenous management, under which ultimate decision-making authority will rest entirely with the Oglala Sioux Tribe (Rights and Resources Initiative, 2015).

Wind Cave differs from the Badlands in the sense that Wind Cave is not located within tribally-owned land. The Badlands (in part) are located on Lakota land; Wind Cave is located on what was formerly Lakota land (and ownership of this land remains contested). The ownership of land in protected areas is typically the factor that causes the most difficulty between protected area authorities and indigenous peoples in the region, with access to land and its resources being the second-most important factor (Beltrán, 2000). It could be predicted that this general rule applies to the situation of Wind Cave National Park and the Lakota people; the Lakotas contest the National Park Services' management authority of the park, feeling that they should rightfully own the land and that the government illegally seized the land from their people. This viewpoint is very strong, evidenced even in the 21 st century on social media by Facebook groups such as "Return the Black Hills." 
Another NPS site in the area plays a role in Lakota cultural tradition, although it is not co-managed. Devils Tower National Monument, located on the western fringe of the Black Hills region in Wyoming, (about a 2-hour drive from Wind Cave) has been the site of a dispute that is especially germane to this discussion. The geologic wonder, called Mato Tipila or Bear Lodge by the Lakotas, is a sacred site for many indigenous groups in the area, including the Lakotas (Dustin et al., 2002). Especially during the month of June (around the summer solstice), the 23 Tribes that claim cultural connections to Devils Tower traditionally hold vision quests, Sun Dances, and other traditional ceremonies at the monument (Dustin et al, 2002). In the 1970s and 1980s, climbers increasingly began utilizing the steep butte, leaving behind permanent bolts and debris (Dustin et al, 2002). Conflict inevitably resulted. Indigenous people protested the social and environmental impacts affected by climbers on Native peoples' ability to perform ceremonies (Dustin et al., 2002). Climbers objected to the prayer bundles left by indigenous people on the rock, and challenged the Tribes' claim to having special rights concerning the monument (Dustin et al., 2002).

In the 1990s, an NPS-sponsored working group, which included both Tribal and climbing representatives, came up with a solution: a voluntary climbing ban (Dustin et al., 2002). Under this agreement, climbers would refrain from climbing during the month of June; they were free to climb during the rest of the year, except during raptor nesting season (Dustin et al., 2002). The NPS would not issue climbing licenses during June, and would improve interpretation regarding indigenous tribes' traditional religious ceremonies and cultural practices (Dustin et al., 2002). The ban was voluntary in nature, so climbers who did not refrain from climbing would not face any legal sanctions (Dustin et al., 2002). 
In 2002, Dustin et al. called the voluntary ban "effective" (p. 85). Chas Cartwright, monument superintendent at the time, reported that the ban resulted in 85\% compliance (Dustin et al., 2002). Rangers would present material about indigenous cultural and religious practices and their significance to visitors who came to the Monument wishing to climb during June, but no coercion was used, and climbers were in no way forced to refrain from climbing (Dustin et al., 2002).

Despite a lack of co-managed parks in the United States, many NPS sites have a relationship to indigenous tribes (Keller \& Turek, 1998). In fact, if one discounts Civil War sites, presidential homes, parkways, and the like, and counts only NPS "crown jewel" National Parks such as Yellowstone, Yosemite, or Grand Canyon, 100\% of these have relationships with indigenous peoples (Keller \& Turek, 1998). In a few cases, indigenous tribes and the NPS have enjoyed long-term, amiable relations characterized by positive attitude statements from both the NPS and the tribe (Keller \& Turek, 1998). Such is the case for the Makahs around Neah Bay and the NPS at Olympic National Park (Keller \& Turek, 1998). But in many other cases, much more negative attitudes are held by indigenous people towards parks all around the country. For example, Keller and Turek (1998) found that many indigenous people living in the northwestern United States in the region of Glacier, Olympic, and Mt. Rainer National Parks, "identified the NPS as just another cog in the federal bureaucracy" (p.XIII). It would logically follow that many should hold negative attitudes towards the parks themselves, although Keller and Turek do not explicitly state whether or not they found this to be the case.

This negative attitude may not be held exclusively toward the National Park Service, but towards government agencies in general, particularly land-holding agencies such as the Forest Service, the Fish and Wildlife Service, and the Bureau of Land Management. The controversy 
surrounding the San Francisco Peaks provides a good example of a sacred site located on a protected area owned by the Forest Service.

The San Francisco Peaks are a volcanic mountain range located within the Coconino National Forest, in northern Arizona. The Hopis, among other tribes in the region, traditionally regard the Peaks as the sacred dwelling place of the kachinas, spiritual beings who help the tribal members (Olsen, 2008). Most of the area immediately surrounding the Peaks themselves is protected by the Kachina Wilderness Area. Several religious shrines have been constructed in the area, and many of them are still in use (Wilderness.net, n.d.).

The Arizona Snowbowl Ski Resort is located within the National Forest on the Peaks, and operates under a special use permit (Mahoney, 2011). Representatives of the Navajo and Hopi peoples opposed a proposed expansion to the ski resort in the early 1980s, arguing in part that the expansion would violate the American Indian Religious Freedom Act (see "United States Laws/Policies Related to Indigenous Peoples", below) and the Establishment Clause, but they were ultimately unsuccessful (Mahoney, 2011). Then in 2002, the resort again proposed expansion, this time including the construction of artificial snowmaking capabilities (Mahoney, 2011). According to the proposal, treated wastewater from the nearby city of Flagstaff would be used to make the artificial snow (Mahoney, 2011). Tribal leaders and representatives spoke of the devastating impacts the artificial wastewater snow would have on their religion and culture, comparing such action to urinating on the Sistine Chapel (Mahoney, 2011). They formalized their complaints in a lawsuit against the Forest Service and two of its forest supervisors, but as in the 1980s, ultimately lost their battle in the courts (Mahoney, 2011).

Although little research has been conducted concerning the attitude of Lakota people toward protected areas, there is no doubt that the many Lakota people hold strong opinions that 
the Black Hills belong to them (Sioux Nation of Indians v. United States, 1979; Worster, 1992; LaVelle, 2001; Afraid of Bear-Cook, 2009; Cook, 2014). Such feelings have been exhibited most strongly, perhaps, by the American Indian Movement, commonly abbreviated and referred to as AIM. Founded in 1968, AIM was an advocacy group that sought civil and human rights for American Indians. Led by Clyde and Vernon Bellecourt, Dennis Banks, and Russell Means (among others,) AIM was originally founded in Minneapolis, Minnesota, home to a large population of impoverished people who had been forced to move from reservations (Matthiessen, 1992; Canby, 2015). AIM at times displayed an attitude of non-violent activism; Martin Luther King, Jr. reached out to the group (Branch, 2006), and one of the organization's better-known events was an organized caravan from Seattle, Washington to Washington, D.C. in protest of the nation's history of broken treaties with indigenous peoples. However, the group at times took a much more aggressive and violent approach; it is also remembered for "Wounded Knee II," a siege of the site of the 1890 federal army's massacre of Lakota men, women, and children. During Wounded Knee II, AIM took 11 hostages and barricaded themselves inside several buildings, holding off federal marshals for over a month before eventually surrendering. The siege resulted in 2 protesters who were killed and 13 more who were wounded, as well as 2 wounded U.S. marshals, including one who was paralyzed (Associated Press, 1973; Worster, 1992; Magnuson, 2010).

The strongest demonstration exhibiting the opinion of rightful Lakota ownership of the Black Hills is Camp Yellow Thunder. Around fifty indigenous people, not all of them Lakota, many of them members of AIM, took possession of a valley in the Black Hills National Forest in April of 1981 (Worster, 1992). They sought to establish a settlement centered around a school that would teach the traditional Lakota way of life (Worster, 1992). Their objectives were part 
spiritual and part political, and they remained for the majority of the decade, until 1988 when the Eighth Circuit Court of Appeals ruled in favor of the Forest Service, which refused to grant the occupiers a special use permit (Worster, 1992). Except for a controversial murder investigation in 1982 (The New York Times Company, 1982), the Camp Yellow Thunder occupation was largely a peaceful event, in stark contrast to the incident at Wounded Knee of the previous decade. The words of Chief Frank Fools Crow offer some insight into the attitude of Lakota people toward the land of the Black Hills: "The Black Hills belong to me. This is a church in itself. This is the foundation of Indian religion" (Worster, 1992, p.108). Although the camp was located in a protected area, the Black Hills National Forest, it seems that no distinction was drawn between the land that lies within the boundaries of the forest and the land outside those boundaries. The fact that the Camp was located in the National Forest, besides being a tactical political move, was arbitrary with regards to the land itself. From this case study, it would seem that attitude toward a particular protected area may be unimportant, for the attitudes that were expressed seem to be directed toward the Black Hills as a whole. The counterpoint to this is the fact that Wind Cave, although located in the Black Hills, is a site of particular significance in Lakota culture (S. Bear Eagle, pers. comm, 5/31/15).

Interestingly, some Lakotas viewed Camp Yellow Thunder as a stunt move by publicityseeking outsiders, and responded by developing their own encampment in Wind Cave National Park, which they called Camp Crazy Horse (Ostler, 2010). Other Lakotas felt that they should have exhausted all legal options before taking such actions, and so opposed this demonstration (Ostler, 2010). The encampment did not last long, and the occupiers generated negative publicity when they left trash behind (Ostler, 2010). 
Despite these strong demonstrations supporting Lakota ownership of the Black Hills, some Lakotas have shown that they have been willing to pay for land in the Black Hills if necessary. A high mountain prairie located near the center of the Hills, Pe Sla Paha is considered sacred by the Lakota tribes and is viewed as some as the center of the universe (Cook, 2014). Unlike Wind Cave and other sacred areas in the Black Hills that are public land, Pe Sla Paha has remained privately owned land (Cook, 2014). In 2014, the Great Sioux Nation (the Lakota tribes) finalized the purchase of the land from the family who owned the property (Cook, 2014). The tribes have petitioned the government to put the land into federal trust status, and they plan to introduce a small herd of bison (buffalo) on the property (Cook, 2014).

To summarize, there are many issues facing park managers when it comes to indigenous people and protected areas. Allowing for the sustainable use of wildlife, plants, and other extractive resources remains an issue of contention in protected areas both in the United States and abroad. Over the past several decades, more and more parks have been moving away from the Yellowstone, "hands-off" approach to management and have become more inclusive in their management policies concerning indigenous people. There has been increasing recognition that the goals of ecosystem preservation and cultural preservation can be complimentary. However, an attitude that parks should be areas of pristine, untrammeled wilderness free of any and all human impact is still held by many, and this is a fundamental issue as parks prepare for the future.

In the area of attitude research towards protected areas, most studies have been conducted outside the Americas. These studies do not provide a clear consensus on attitude, and most do not adequately define attitude. Despite the lack of research concerning the attitudes of indigenous people in the United States toward national parks, Keller and Turek (1998) found 
preliminary evidence to suggest negative attitudes were held by indigenous groups in the Pacific Northwest toward three national parks. In the case of the Lakota people, it is clear that many hold the firm belief that the Black Hills, in their entirety, belong to the Lakota people themselves and not the United States government.

\section{United States Federal Laws/Policies Related to Indigenous Peoples}

"Indian law" is the term used by the United States to refer to laws dealing with its relationship to indigenous tribes (Canby, 2015). Judge William C. Canby, Jr. proposed four major themes that form the basis of federal Indian law: (1), tribes are sovereign entities with inherent powers of self-government; (2), Congress' power over tribes is plenary, or absolute; (3), the power to deal with tribes is exclusively federal; and, (4), the federal government has a responsibility to protect tribes, which has been described as a trust relationship (with the United States as the trustee and the tribes as the beneficiaries) (Canby, 2015).

Tribes' unique position as "sovereigns within a sovereign" creates difficulty when characterizing tribal sovereignty. Historically, European powers signed treaties with tribes, recognizing their sovereignty, while simultaneously claiming dominion over newfound land, seemingly placing a limit on that sovereignty (Canby, 2015). In 1823, Chief Justice John Marshall placed a serious limit on tribal sovereignty when he ruled that tribes had no power to grant land to any entity other than the United States' federal government (Johnson v. McIntosh, 1823). However, nearly a decade later, in 1831, Marshall ruled that tribes are independent states that have the power to self-govern independent of the United States, characterizing tribes as “domestic dependent nations" (Cherokee Nation v. Georgia, 1831). Thusly, the sovereignty of tribes is, in theory, subject to two limitations: the ability to convey land and the ability to deal with foreign states (Canby, 2015). Over the years, however, courts have further limited tribal 
sovereignty through a plethora of cases (Canby, 2015). Significantly, however, tribes' power to self-govern is inherent; it is not granted by the federal government (Canby, 2015). One of the most important ways the United States has recognized this right is through treaties.

The European powers that settled what would become the United States signed treaties with the tribes they encountered, and the United States' federal government continued the practice of treaty-making with tribes until 1871 (Canby, 2015). A treaty is an agreement between two sovereigns, and the United States' practice of signing treaties with tribes effectively recognized the sovereignty of tribal nations (Canby, 2015). Rights that many tribes deem important were originally secured by treaty and continue to be enforced today; moreover, other treaties have been held enforceable after long periods of dormancy, as was the case in Minnesota v. Mille Lacs Band of Chippewa Indians (1999) (Canby, 2015).

Running contradictory to the above discussion, Congress' power over Indian tribes is absolute (United States v. Lara, 2004). Such complete power may seem unfair and has been the subject of criticism (Red Lake Band of Chippewa Indians v. Swimmer, 1990). However, provided that Congress makes clear its intent to limit tribal sovereignty, it has the complete power to do so (United States v. Lara, 2004). Unlike Congress, States have no power over tribes (unless Congress grants them such power) (Worcester v. Georgia, 1832). Dealing with tribes is an exclusively federal privilege.

In Cherokee Nation v. Georgia (1832), John Marshall stated that tribes" "relation to the United States resembles that of a ward to its guardian” (17). The United States, then, has a responsibility to protect the tribes, as would any guardian. The degree of legal enforceability of this responsibility, however, differs depending on subject matter and branch of government (Canby, 2015). Courts have sometimes enforced the fiduciary duty of the executive branch 
(Canby, 2015). However, no court has ever made a similar ruling concerning Congress (as of the time of this writing), and so the fiduciary responsibilities of the legislative branch are essentially moral (Canby, 2015).

Besides these four general themes of federal Indian law, a few specific examples of legislation warrant specific attention. The First Amendment of the Constitution guarantees to every United States citizen the right of free exercise of religion (U.S. Const. amend. I). Since many indigenous religious practices are closely tied to particular objects or places, Congress passed the American Indian Religious Freedom Act (AIRFA) in 1978 (Canby, 2015). AIRFA guarantees to indigenous peoples the "inherent right of freedom to believe, express, and exercise [their] traditional religions...including but not limited to access to sites, use and possession of sacred objects, and the freedom to worship through ceremonials and traditional rites" (American Indian Religious Freedom Act of 1978, 1996). Additionally, Executive Order 13007 (1996) directs federal land management agencies to grant indigenous peoples access to federal lands for religious ceremonies to the extent practicable, provided that such access is in line with agency functions.

However, AIRFA has proven to be a law with "no teeth." In Lyng v. Northwest Indian Cemetery Protective Association (1988), the Supreme Court ruled that as long as the federal government did not coerce individuals into violating their religious beliefs or penalize religious activity, it was free to do with its land what it saw fit. Therefore, AIRFA includes "no judicially enforceable private right of action" (Canby, 2015, p.392). The Religious Freedom Restoration Act (1993) was a response that prohibited the government from substantially burdening one's practice of religion, unless such burden furthers a compelling government interest, and such burden represents the government's least intrusive means of action to further this interest. 
President Obama took further action during his administration to emphasize the importance of tribal consultation. A memorandum issued in 2009 condemns the failure of the federal government to consult with tribes when constructing policy that affects those tribes. The memorandum includes increased accountability measures for the Secretary of the Interior (as well as the other federal secretaries) (Obama, 2009). Executive Order 13647 (2013) echoes the previously issued memorandum, calling once again for increased consultation with tribes for any federal policy that may have an effect on those tribes.

\section{Life on a Reservation}

The treaties mentioned in the preceding section often contained provisions for ceding land (Canby, 2015). When land was ceded, treaties often contained provisions for a tribe to "reserve" some of the land for its own people, creating reservations (Canby, 2015). There are many distinct differences between growing up on a reservation as opposed to growing up off of one. The closest reservation to Wind Cave is the Pine Ridge Indian Reservation, located in southwestern South Dakota, on the plains and badlands east of the Black Hills. About 70 miles of road separate the Wind Cave National Park visitor center and the community of Pine Ridge, the tribal headquarters and the largest population center on the reservation (Reinhardt, 2015). Pine Ridge, established in 1889, is one of 9 reservations in South Dakota that are home to Lakota, Nakota, and Dakota people (Johnson, 2009). These three groups speak different language dialects and have been collectively referred to as the "Sioux" (Ostler, 2010). Pine Ridge, while home to a few Sicangus (or Brulés), is the designated reservation of the Oglalas, one of the seven bands of the Lakota people (Reinhardt, 2015). Pine Ridge is the largest in population and third largest in area of 9 reservations in South Dakota (Johnson, 2009). 
According to the South Dakota Department of Tribal Relation's website, the total membership of the Oglala Sioux Tribe was 38,332 in 2011 (the most recent year available) (South Dakota Department of Tribal Relations, 2011). Of those members, 19,639 lived on Pine Ridge Reservation (SD Dept. of Tribal Relations, 2011). Many Oglalas live off of Pine Ridge Reservation, and the cities of Rapid City, South Dakota, and Gordon and Rushville, Nebraska, all have significant populations of Oglalas. According to 2010 US census data, there were about 8,400 (12\%), $240(15 \%)$, and 163 (18\%) people who identified themselves as American Indian living in Rapid City, Gordon, and Rushville, respectively (United States Census Bureau, 2015). Life on Pine Ridge Reservation contrasts sharply with the life many Americans experience. Median household income on the reservation was $\$ 20,568$ compared to $\$ 49,495$ in South Dakota and \$51,672 in Nebraska (US Census Bureau, 2015). Unemployment rate on the reservation was $24.1 \%$ as reported by the US Census Bureau (US Census Bureau, 2015) and $89.0 \%$ as reported by the Department of the Interior (US Department of Interior, 2005) ${ }^{1}$; South Dakota had an unemployment rate of 3.5\%, and Nebraska 4.0\% (US Census Bureau, 2015). Over $53 \%$ of reservation residents lived below the poverty line, compared to $14 \%$ in South Dakota and just under 13\% in Nebraska (US Census Bureau, 2015). The average lifespan of a male on Pine Ridge Reservation is 44 years old (American Indian Humanitarian Foundation, 2014); the average lifespan of a male living in the United States is 76 years (World Health Organization, 2015). In 2010 Pine Ridge High School, the largest on the reservation, had a four-

\footnotetext{
${ }^{1}$ This discrepancy has to do with how the two agencies define unemployment. The Census Bureau defines unemployment rate as the percentage of persons who have not worked during the monthly survey period, are available for work, and have actively sought a job during the 4 weeks prior to being surveyed (US Census Bureau, 2015). The Department of the Interior, for its 2005 report on American Indian labor, defined unemployment rate as the percentage of persons between the ages of 16 and 64 who are available for work, are not disabled or incarcerated, and do not work for money (US Department of the Interior, 2005). The main difference between these two definitions is the Census Bureau's requirement that a person must have actively sought a job over the prior 4 weeks to be included as part of the labor force. Those persons who have essentially "given up" seeking employment are not reflected by the Census Bureau's statistic, but are included in the Department of the Interior's figure.
} 
year graduation rate of 45\% (Maxwell 2013); South Dakota's was 83\% (Strauss 2015).

Freedenthal and Stiffman (2004) compared a group of American Indian youth living offreservation to those living on-reservation (a reservation other than Pine Ridge was used for the study), and found higher numbers of suicide ideation and psychosocial problems among the reservation group.

Plas and Bellet (1983) found sufficient evidence, including statistics similar to those mentioned above, to justify the development of a separate value-attitude assessment from the one normally used that targeted use with indigenous children in the United States. The instrument relied on auditory stimuli, in contrast to the more traditional personality/attitude assessments which rely on written and/or pictoral stimuli (Plas and Bellet, 1983). Plas and Bellet reasoned that "most Indian children grow up in relatively unpopulated areas of the country" (p. 59), which could be read as "on a reservation". They thus learn to relate to their environment through the auditory channel.

Plas and Bellet also identify several differences in social constructs between American indigenous cultures and anglo-American cultures based on the literature. American indigenous cultures tend to value non-interference in the affairs of others; indirectness when changing topic of conversations or redirecting attention; a sense of community; a sense of time not necessarily based on clock time; and a lesser focus on formal education (Plas and Bellet, 1983).

\section{Interpretation and Its Relevance to Wind Cave and Lakota Relations}

Interpretation has been defined in a variety of ways (Knapp et al., 1997). Freeman Tilden's landmark Interpreting Our Heritage (1957) remains the most cited framework for interpretation (Vander Stoep, 1991). Tilden (1957) describes interpretation as "an educational 
activity which aims to reveal meaning and relationships through the use of original objects, by firsthand experience, and by illustrative media, rather than simply to communicate factual information." Sam Ham (1992) calls interpretation, "translating the technical language of a natural science or related field into terms and ideas that people who aren't scientists can readily understand," and Knudson et al. (1995) define interpretation as "the translation of historic, cultural, or natural phenomena to increase audience understanding or enjoyment."

At Wind Cave National Park, cave tours are offered year-round (National Park Service, 2015e). In addition to cave tours, campfire programs occur during the summer at the campground amphitheater, bird walks are offered during July beginning at the visitor center, prairie night hikes are offered two nights a week during the summer, and elk bugling program takes place during the fall (NPS, 2015e). In the visitor center, interpretive exhibits give visitors information about both the cave and the prairie ecosystem (T. Firkins, pers. comm., May 19, 2015).

Interpreters at Wind Cave are not given a script for cave tours; rather, they are expected to develop their own programs for cave tours (T. Firkins, pers. comm., 5/19/15). Interpreters are given a list of several broad themes for all park programs as a guideline; all tours must somehow relate back to one or more of these already-established themes (T. Firkins, pers. comm., 5/19/15). A written version of the Lakota Emergence Story, a traditional story depicting the importance of Wind Cave and its place in Lakota culture, is available at the information desk in the visitor center (T. Farrell, pers. comm., July 20, 2015). Interpreters are expected to at least give a synopsis of the Emergence Story (S. Bear Eagle, pers. comm., July 29, 2017) and mention the availability of the written version of the story on their tours (T. Farrell, pers. comm., 1/26/16). In 
addition, an interpretive sign located at the Natural Entrance to the cave gives a brief summary of the story as well (T. Farrell, pers. comm., May 20, 2015).

Albers (2003) gives several recommendations for incorporating tribal perspectives into interpretation at Wind Cave. She notes that two differing opinions exist concerning the incorporation of indigenous culture into park interpretive programming; although there are those who believe that the park has no business involving itself in the cultural history of local tribes, the vast majority of tribal members believe their cultural perspectives need to be a part of park interpretation (Albers, 2003). Although most tribal members believe that certain aspects of their culture should not be shared with the public, there are many subjects that aren't especially sensitive in nature that can be incorporated into interpretive materials (Albers, 2003). She suggests that hiking trails be used to interpret tribal perspectives of natural history at the park, and suggests focusing on certain animals and landforms that hold special significance in Lakota and other tribal traditions (Albers, 2003). She specifies that tribal perspectives should not be treated as a concept of the past, but rather as a continuing body of knowledge (Albers, 2003). As of 2003, Albers notes that "the tribal side to the natural and cultural history has remained conspicuously absent in various educational venues" (p. 646). However, since 2003, a sign placed at the Natural Entrance describing the discovery of the cave by European settlers was replaced by the one mentioned above in 2014; the written version of the Lakota Emergence Story has been made available to park visitors; and an increased emphasis has been made on incorporating tribal perspectives into the interpretation of the park (T. Farrell, pers. comm., $7 / 20 / 15)$

The park is beginning to plan for the installation of new interpretive exhibits in its visitor center; this provides another opportunity for incorporating tribal perspectives into its 
interpretation (T. Farrell, pers. comm., November 2, 2015). Yet another opportunity exists at the Casey (or Sanson) Ranch property. This property was acquired in October of 2011, and includes many tipi rings and an alleged historic buffalo jump (NPS, 2011). Although public access has only been available as part of weekly tours during the summer, park staff are currently in the planning process of developing the property for more open public access (T. Farrell, pers. comm., 11/2/15). 


\section{Chapter 3: Methods}

RQ 1: What are the attitudes of Lakota people towards Wind Cave National Park?

RQ 2: What are the attitudes of Lakota people toward the National Park Service's interpretation of Wind Cave?

RQ2a: What are the attitudes of Lakota people towards the National Park Service's personal interpretation of Wind Cave, i.e. a cave tour?

RQ2b: What are the attitudes of Lakota people towards the National Park Service's nonpersonal interpretation of Wind Cave, i.e. exhibits in the visitor center?

RQ 3: What are the attitudes of Lakota people toward non-indigenous people entering Wind Cave?

RQ 4: Do the above attitudes differ depending on age?

The population for this study is the enrolled members of Lakota tribes of the region surrounding the Black Hills. The majority of interviewees were members of the Oglala Sioux Tribe, the tribe of the Pine Ridge Reservation, although a few were members of other tribes (Cheyenne River Sioux Tribe, Rosebud Sioux Tribe). Although there are presumably enrolled tribal members who have moved a sufficient distance away from the Black Hills that they no longer physically encounter the land on a regular basis, the population was limited to those people who were living in the vicinity of the Hills at the time of the study.

Criterion sampling is a type of purposive sampling outlined by Palinkas et al. (2015). In this type of sampling, subjects are identified and selected based upon one or more predetermined criteria. This study originally sought to sample tribal members on two criteria: age and place of residence (within or outside the boundaries of Pine Ridge Indian Reservation). The variable of interest in RQ4 is age. The aim was to have roughly equal numbers of adults over the 
age of 44 and those under the age of 44 make up the sample. Interviewees were broken up into two categories based upon age: those between the ages of 18-44, and those 45 and older. Due to the small target sample size, having more age groups would have made it too difficult to analyze in order to find any difference. This study was limited to legal adults; no one under the age of 18 was included in the sample. Anthony (2007) found differing attitudes toward a protected area based upon age (younger people were more likely to hold a positive attitude toward the protected area). Therefore, it is not unreasonable to investigate whether attitudes towards Wind Cave National Park vary depending upon age. Also, according to recent estimates, the average lifespan of a Lakota person is about 44 years for males and 52 years for females (American Indian Humanitarian Foundation, 2014). People are consequently considered as being “older" at a relatively young age; for this reason, many people start families at a younger age, often even during their teenage years (S. Bear Eagle, pers. comm., November 11, 2015). Using the age for males as a guideline, 44 was used as the "dividing age," dividing the population into an "older" group and a "younger" one.

Originally, an additional Research Question dealt with the criterion of place of originwhether one grew up on or off of an American Indian reservation. The aim was to have roughly equal numbers of adults who grew up on the reservation and those who grew up off the reservation in the sample. The term "growing up" can be somewhat nebulous; disagreement could exist over what years constitute when one "grows up," and it frequently happens that people "grow up" in more than one place, as is often the case for children in military families in the United States, or for those whose parents are divorced and split time between two homes. Adolescence is widely considered a time for great growth, change, and development (Erikson 1950, 1963; Turiel 2010; Nucci \& Gingo 2011; Smetana et al. 2015), and so "growing up" is 
equated to adolescence (roughly defined by Erikson as ages 12-18). If someone spent his adolescence living on the reservation, he was to be considered as having grown up on the reservation. If someone spent his adolescence living off the reservation, he was to be considered as having grown up off of the reservation. If someone spent parts of his adolescence both on and off the reservation, he was to be counted in a third category made up of those persons who spent parts of their adolescence both on and off the reservation.

Unfortunately, due to unforeseen difficulties, Lakota people who grew up off of a reservation could not be adequately accessed. Out of 17 interviews conducted, only 2 were with people who grew up exclusively off of a reservation. Therefore, differences in attitudes based on where one grew up could not be sufficiently assessed, and the research question dealing with this subject was removed from the study. In addition to the two criteria mentioned above, another aim was to have roughly equal proportions of men and women in the sample in order to avoid any bias.

Although criterion sampling is useful in qualitative research, oftentimes using more than one method may be the most appropriate technique (Palinkas et al, 2015). In addition to criterion sampling, another purposive sampling method known as snowball sampling or chain sampling was used (outlined by Goodman (1961), Browne (2005), Noy (2008)). The researcher had a contact who was a member of the Oglala Sioux Tribe. She was female, under 44 years of age, and grew up both on Pine Ridge Indian Reservation and off reservation land; she had worked as an employee at Wind Cave National Park. She was asked for the names of 5-10 people who could potentially be interviewed. Each person was contacted by phone and asked for permission to be interviewed. Each potential interviewee was also asked if he/she was willing to have the interview recorded using a digital voice recorder and later transcribed. In the case that someone 
agreed to be interviewed but did not wish to be recorded, notes were taken by hand. This only occurred for one out of 17 interviews. Interviews were kept confidential and interviewees' names were not attached to their responses in any way.

After interviewing those who agreed to be interviewed, each was asked for the names of other people who could potentially be interviewed, and the sample continued to "snowball" in this manner. This method especially lends itself to sensitive or controversial topics (Biernacki and Waldorf, 1981; Browne, 2005; Noy, 2008), and the relationship between indigenous peoples and European-Americans in the Black Hills certainly qualifies as such.

There are obvious drawbacks to this method, several of which are outlined by Biernacki and Waldorf (1981) and Sadler et al. (2010). This technique did not result in a random sample. In fact, this method can lend itself to bias - when asking someone for the names of other potential interviewees, he/she will likely send the interviewer to like-minded friends. However, the goal of this qualitative study was not to make generalizations that can be applied to other groups, but rather, to learn more about the attitudes of individual Lakota people (those being interviewed) toward Wind Cave National Park. Because the primary aim was not to make generalizations, and because it was virtually impossible to obtain a random sample due to logistical constraints (mainly time and money), snowball sampling was the most appropriate method for this study.

The aim was to conduct somewhere between 15 and 30 interviews. Since making generalizations from this study was not a goal, it was not helpful to simply conduct as many interviews as possible. According to Marshall (1996), the exact number of required subjects (somewhere between 15 and 30) should become obvious during any snowball sample study, as new patterns and information stop emerging (a condition known as data saturation). Three 
criteria were originally included (age, gender, where one grew up) in the sample, and an aim was to ensure approximately equal numbers of people in the sample fell into each of nine categories based on those criteria. In the end, 17 interviews were conducted. There were roughly equal numbers of men and women and those over and under the age of 44 . However, the vast majority of those interviewed grew up on a reservation, and so the variable dealing with where one grew up was removed from the study.

A general interview guide approach was used, outlined by Turner III (2010). This approach employs the use of structured questions that have been developed before the interview, but allows flexibility for the interviewee to share other important thoughts concerning the topic that may not be in direct response to the questions asked (Turner III, 2010). The interview guide used to conduct interviews was based on the one used by Allendorf (1999). This model was originally used in Nepal; obviously, questions were adapted for use in the Black Hills concerning the Lakotas and Wind Cave National Park. See Appendix A for interview guide.

The initial questions were aimed at building rapport and obtaining limited demographic information necessary for Research Question 4. All other questions asked were tied to the research questions 1-3 (Appendix A). Research Questions 1 was addressed first, and the latter questions of the interview sought to answer Research Questions 2 and 3.

The Consultation with Native Americans publication (published in part by the National Park Service) recommends that interviews with indigenous peoples be conducted face-to-face (Federal Preservation Institute, n.d.). All but one interview was conducted on-site and in-person; due to logistical constraints, one interview was conducted over the phone. All interviews took place from June 2016 to August 2016. All in-person interviews were recorded using a digital voice recorder, unless the interviewee did not agree to be recorded. In the one case in which this 
occurred, notes were taken by hand. The telephone interview was recorded and transcribed using the telephone service No Notes. The interviews were transcribed using Microsoft Word, and the completed transcripts from each interview were uploaded into the cloud-based computer coding program Dedoose.

Content analysis was used to review each interview transcript; each line was examined for phrases or terminology that fell into any of the coding categories. Some coding categories had been set up a priori. Other coding categories emerged during the content analysis process, and these categories were added to the a priori categories. 


\section{Chapter 4: Results}

Many codes emerged during content analysis of interview transcripts. Most of the codes generated were positive or negative attitude statements that fell into one of three categories depending on the object of the attitude. Attitudes were expressed towards Wind Cave National Park as a whole (RQ1), the interpretation that takes place at Wind Cave National Park (RQ2), and non-indigenous people entering Wind Cave (RQ3). How those attitudes differ depending on age, if at all, are then examined (RQ4). In addition, codes emerged that expressed significance of Wind Cave to Lakota interviewees, and suggestions that interviewees had for improvement at Wind Cave National Park. Throughout this chapter, representative quotes will be used to contextualize the results being presented.

Generally speaking, most people expressed both positive and negative feelings during their interviews. Twelve out of 17 people (71\%) expressed both positive and negative feelings towards Wind Cave National Park in general, and 10 out of 17 people (59\%) expressed both positive and negative feelings toward the interpretation at Wind Cave National Park. Furthermore, 4 people (24\%) explicitly stated that they had mixed feelings towards the park. The following results section is organized by research question. The attitude statements made by those interviewed are broken down and put into one of three categories, depending on whether they relate to the park in general, the interpretation, or tourists on cave tours.

\section{Research Question \#1: What are the attitudes of Lakota people toward Wind Cave}

\section{National Park?}

Fifteen out of 17 people interviewed (88\%) expressed positive thoughts or feelings towards Wind Cave National Park (see Figure 1), as stated in Interview 16: “...going through, it's just really welcoming. ... all in all, it's a great place." The most commonly reported themes 
associated with these positive comments were as follows (see Figure 2): Preservation or protection of resources (10 people or 59\%); the natural beauty of the Park (6 people or 35\%); the wildlife in the Park (5 people or 29\%); improvement at the Park (5 people or $29 \%$ ); and the Park was willing to make positive changes (3 people or $18 \%$ ).

Fourteen out of 17 people interviewed (82\%) expressed negative thoughts or feelings toward Wind Cave National Park (see Figure 1). The most common themes associated with these negative comments were as follows (see Figure 3): Wind Cave is a tourist attraction (9 people or 53\%); Lakota perspectives are not properly represented or emphasized at the park (8 people or 47\%); the park charges fees in order to access Wind Cave (5 people or 29\%); the park's understanding of Lakota perspectives is factually inaccurate (4 people or 24\%); the federal park is a violation of the Fort Laramie Treaty of 1868, and the federal land should belong to the Lakotas and be under their control (4 people or $24 \%$ ); and the park is generally unwelcoming and/or disrespectful towards Lakota people (4 people or 24\%), as one interviewee stated: “Apparently, there's no inclination, or supporting from the National Park Service for people to stay. ...I have a sense that they don't want people to stay there, just come through and go" (Interview 9). 


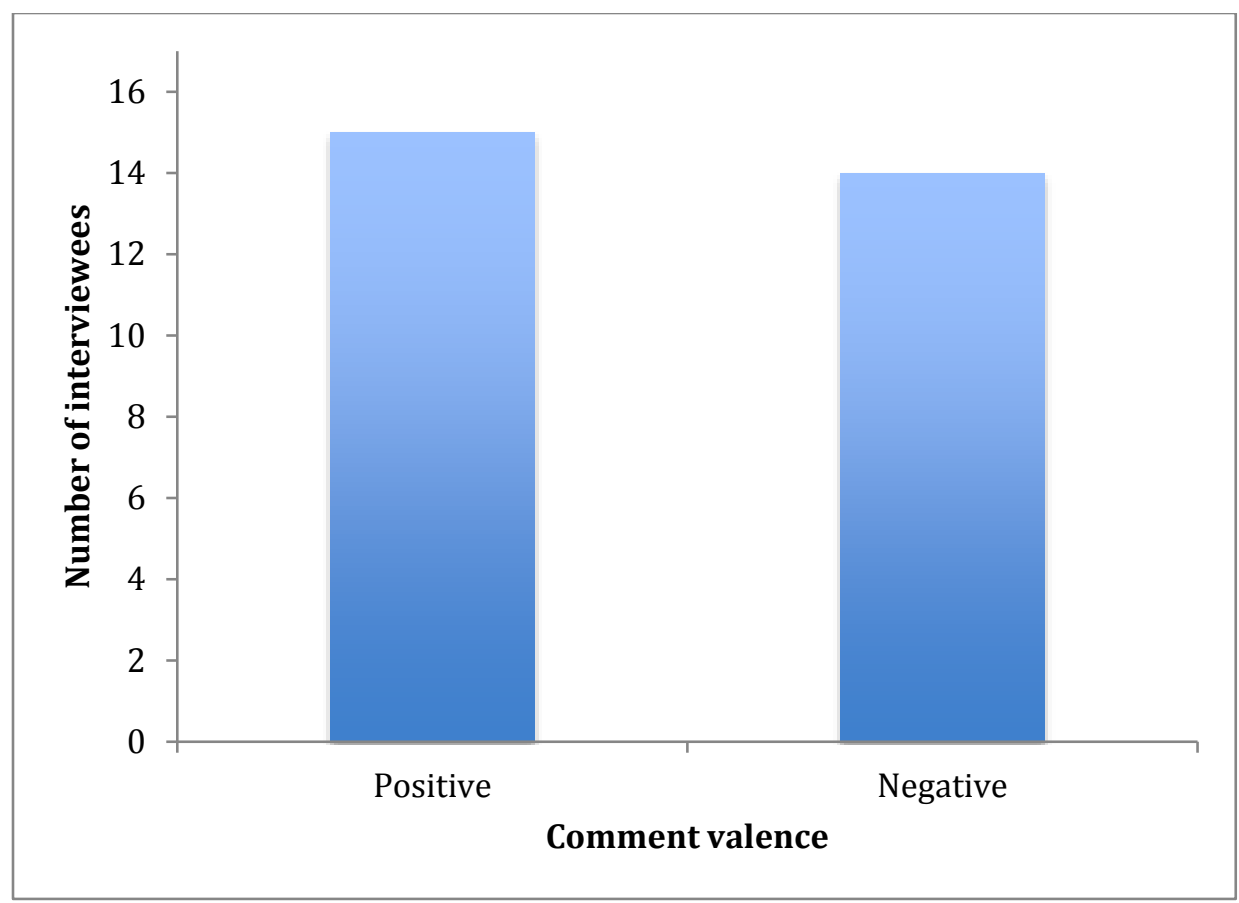

Figure 1. Number of interviewees who made positive or negative comments towards Wind Cave National Park.

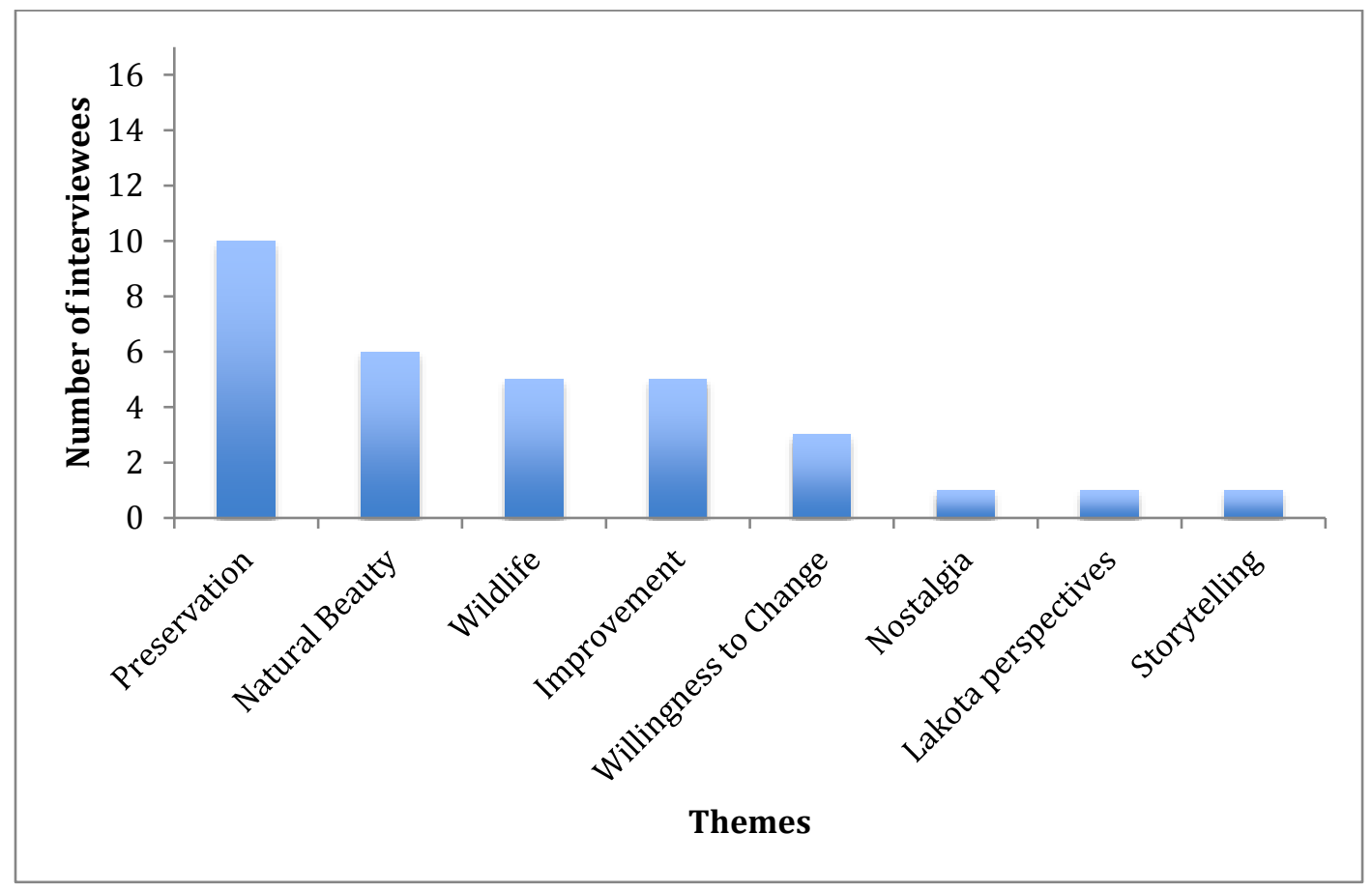

Figure 2. Most commonly reported positive comments about Wind Cave National Park. 


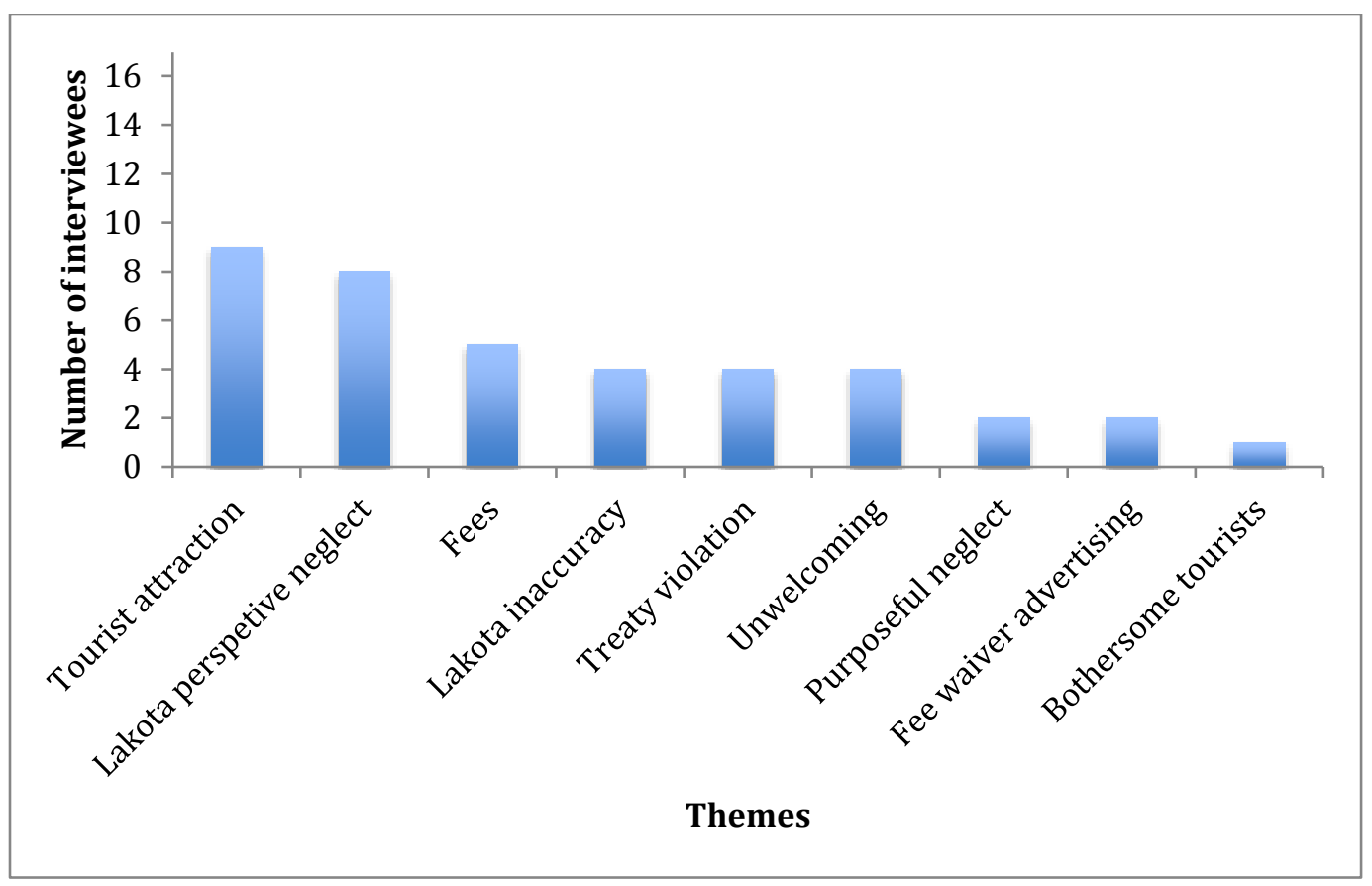

Figure 3. Most commonly reported negative comments about Wind Cave National Park.

Research Question \#2: What are the attitudes of Lakota people toward the National Park Service's interpretation of Wind Cave?

Ten out of 17 people interviewed (59\%) expressed positive thoughts or feelings toward interpretation at Wind Cave National Park. All 17 people (100\%) expressed negative thoughts or feelings toward the interpretation at the Park (see Figure 4). 


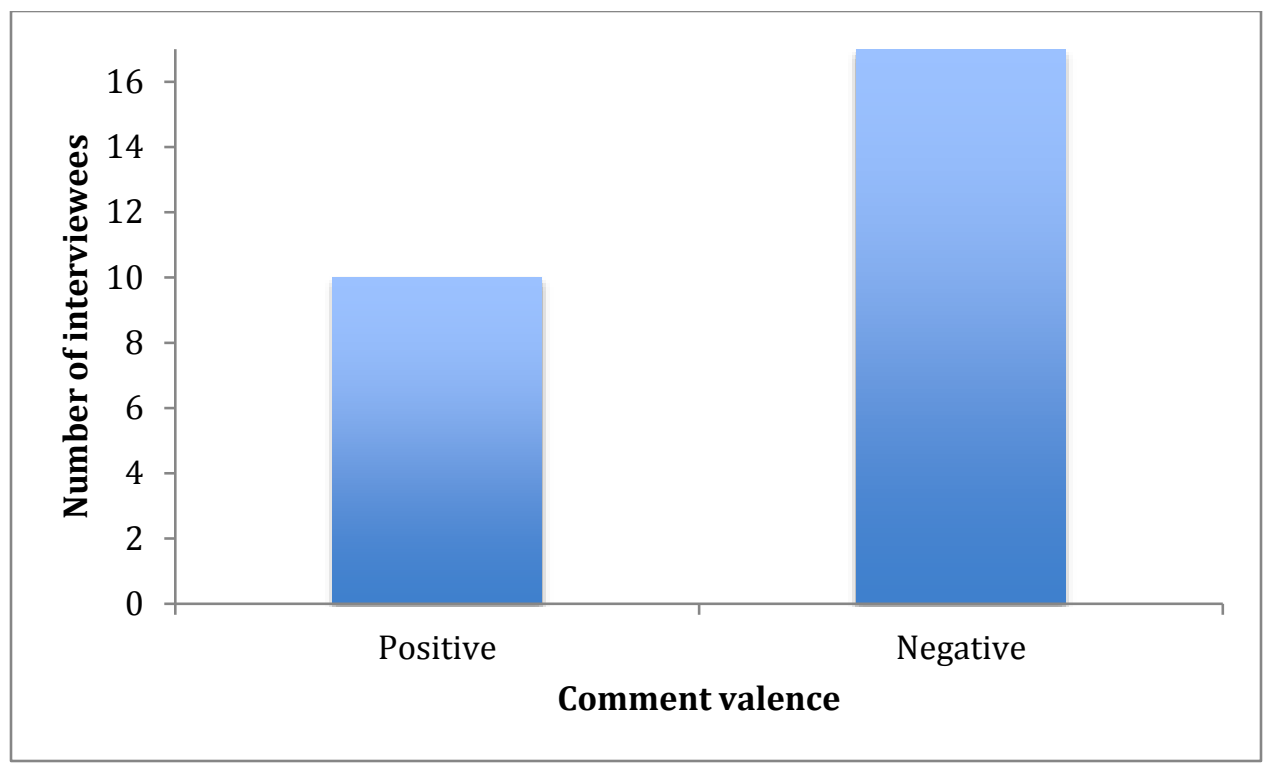

Figure 4. Number of interviewees who made positive or negative comments towards the interpretation at Wind Cave National Park

Research Question \#2a: What are the attitudes of Lakota people towards the National Park Service's personal interpretation of Wind Cave, i.e. a cave tour?

Eight out of 17 people (47\%) expressed positive thoughts or feelings towards cave tours at Wind Cave National Park (see Figure 5). The most commonly reported theme was pleasure with the inclusion of Lakota perspectives on cave tours, as the following person said: “...I really liked the tour that the ranger gave us. ...from what I've heard, she told the [Emergence] Story very accurately, and she gave a lot of information." (Interview 7). This theme emerged in 5 interviews (29\%); the second-most commonly reported theme was the scientific information shared on cave tours (3 people or 18\%).

Twelve out of 17 people (71\%) expressed negative thoughts or feelings towards cave tours at the Park (see Figure 5). The most commonly reported theme associated with these negative comments was that the tours did not adequately emphasize or respect the Lakotas' viewpoints of Wind Cave (9 people or 53\%); as one interviewee stated, "If anything was 
mentioned about the Lakota people, it was mentioned in passing. Entirely. And that's actually still a problem that exists." (Interview 11). See Figure 7 for additional comments.

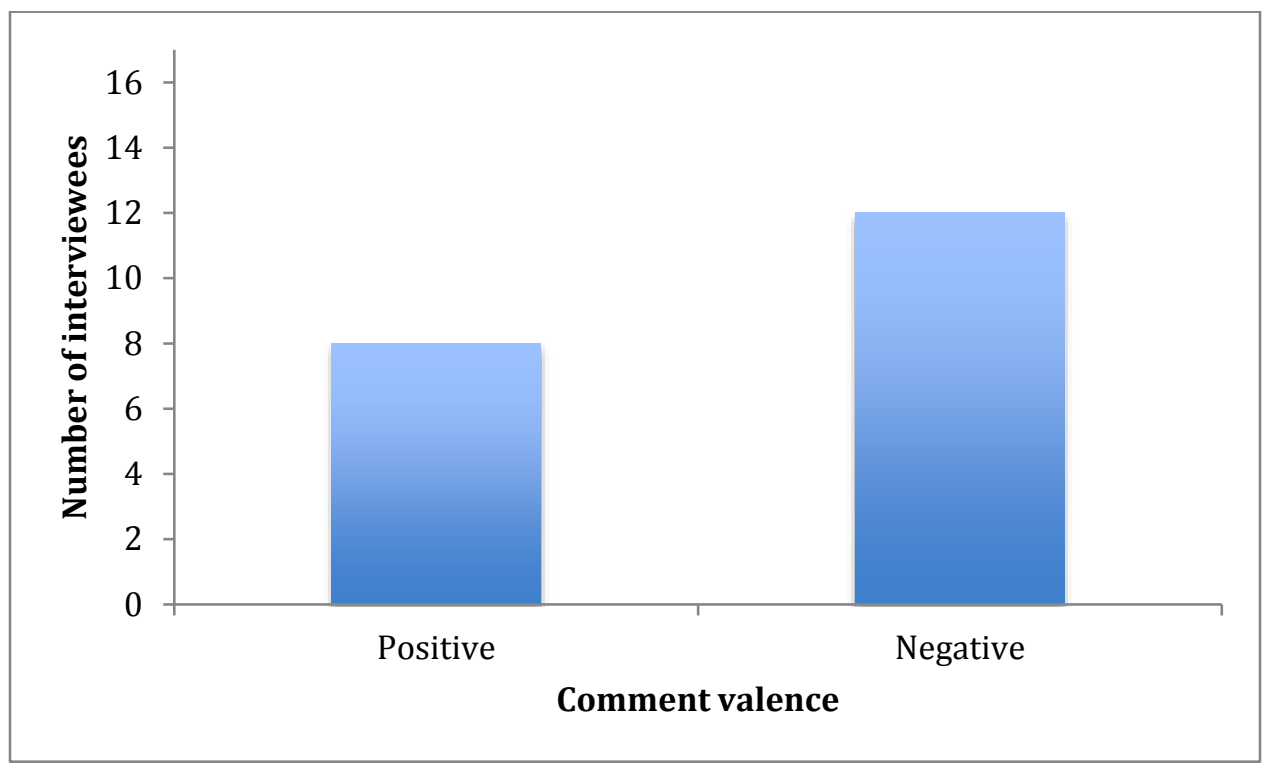

Figure 5. Number of interviewees who made positive or negative comments about cave tours at Wind Cave National Park

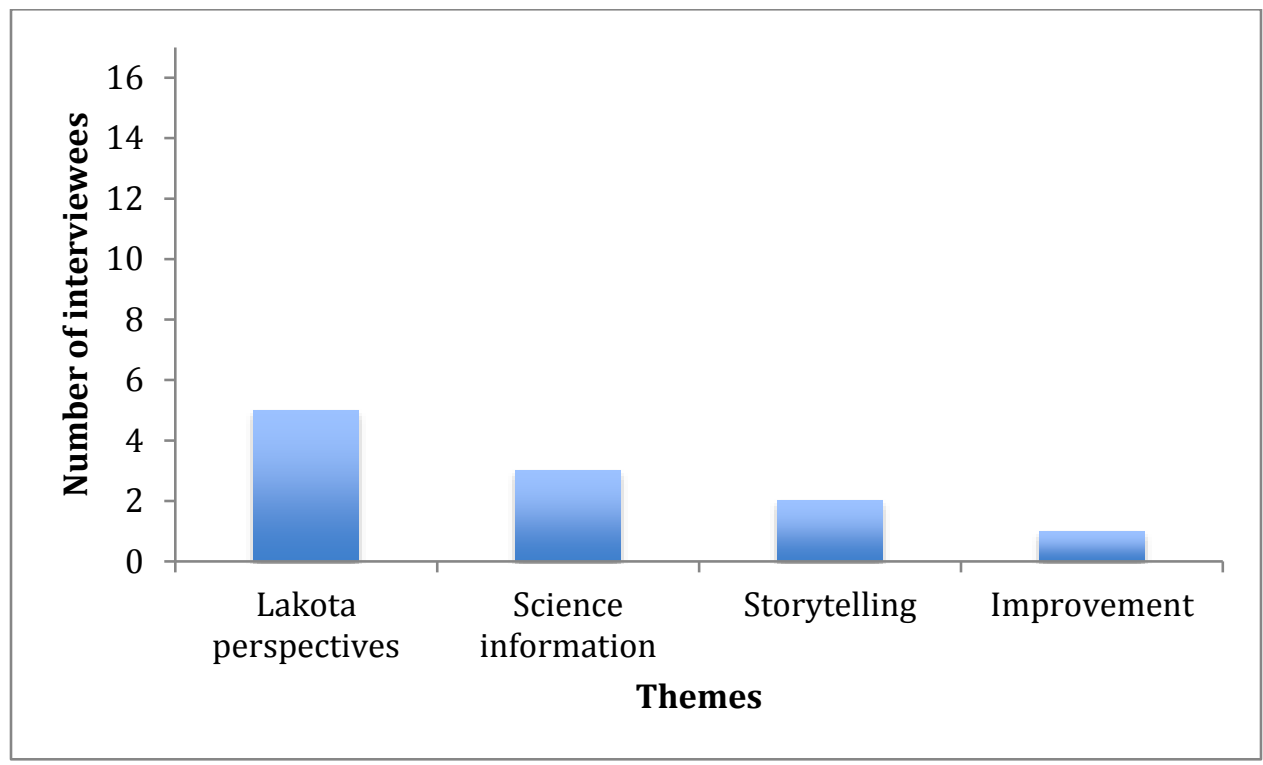

Figure 6. Most commonly reported positive comments about cave tours at Wind Cave National Park 


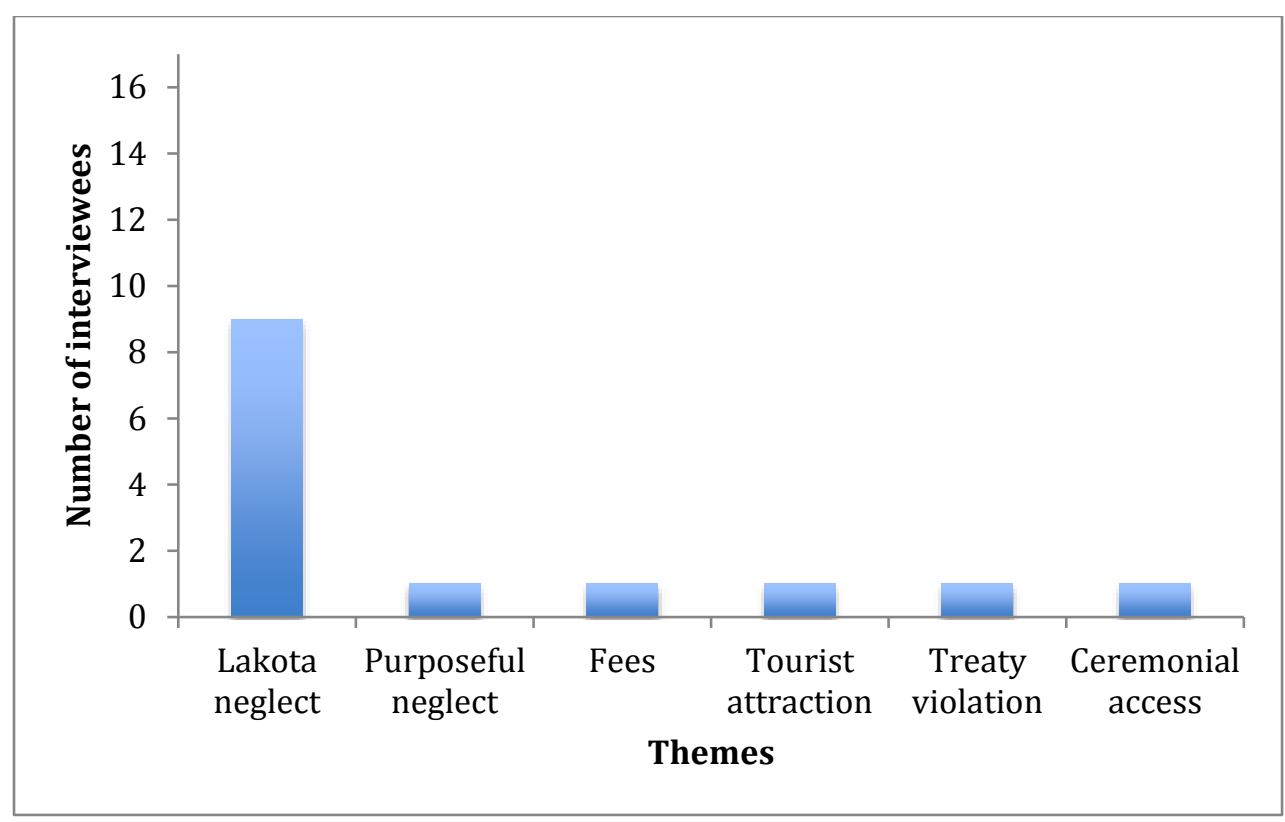

Figure 7. Most commonly reported negative comments about cave tours at Wind Cave National Park.

Research Question \#2b: What are the attitudes of Lakota people towards the National Park Service's non-personal interpretation of Wind Cave, i.e. exhibits in the visitor center?

Three out of 17 people (18\%) expressed positive thoughts or feelings towards the visitor center exhibits at Wind Cave National Park (see Figure 8). A quote from one interviewee, "I think the park is willing to make changes, " (Interview 11), is illustrative; all 3 of these people commented that improvements are being planned for the exhibits.

Twelve out of 17 people (71\%) expressed negative thoughts or feelings toward the visitor center exhibits at Wind Cave National Park (see Figure 8). The most common theme was that Lakotas' viewpoints are not adequately represented in the exhibits: “You know, it's very dismissive, it's very insulting. The time periods that are addressed with regard to Native Americans are past tense. I mean, we don't exist anymore. I think the exhibits with regards to Lakotas at Wind Cave is almost like-oh yeah! We got to say something about the Indians." (Interview 17). This theme was expressed by 10 people (59\%). The other two most commonly 
reported themes associated with these negative comments were that information contained in the exhibits is inaccurate (3 people or 18\%); and the neglect of Lakota's perspectives is purposeful on the part of the park (3 people or 18\%).

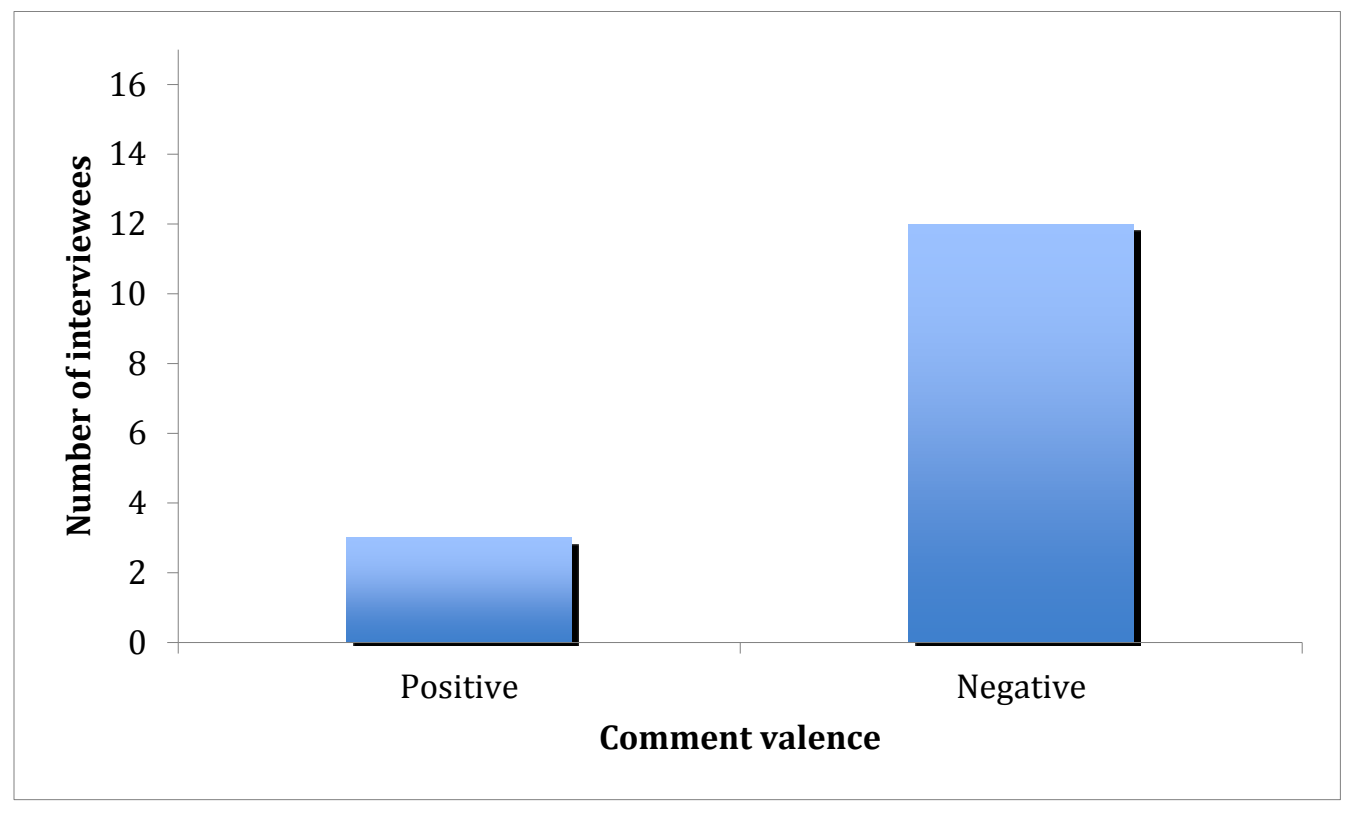

Figure 8. Number of interviewees who made positive or negative comments about Visitor Center exhibits at Wind Cave National Park.

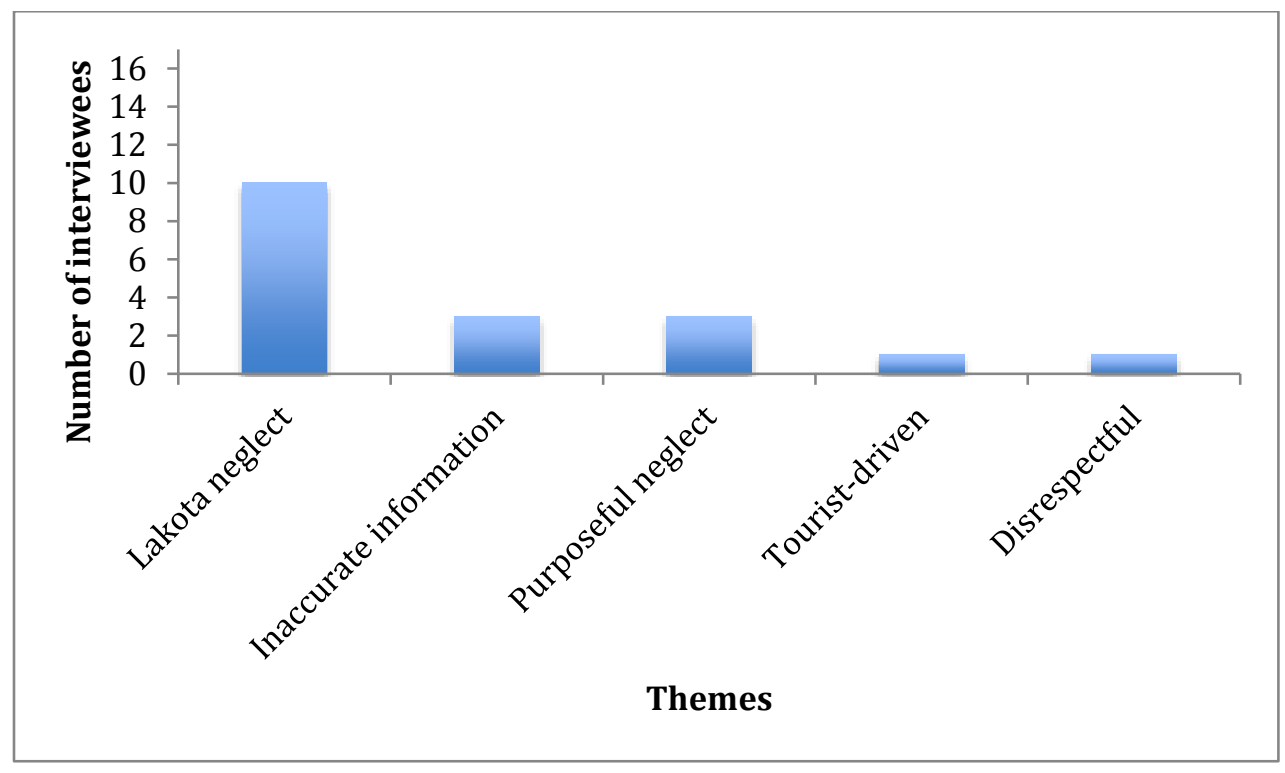

Figure 9. Most commonly reported negative comments about Visitor Center exhibits at Wind Cave National Park. 


\section{Research Question \#3: What are the attitudes of Lakota people toward non-indigenous people entering Wind Cave?}

Thirteen out of 17 people interviewed (76\%) expressed positive thoughts or feelings about non-indigenous people entering Wind Cave (e.g., on a cave tour) (see Figure 10). Many of these people had comments such as, "I'm not too perturbed by the idea of other people experiencing that place too, you know? It's a powerful place, it's a beautiful place.... I think that as long as that story is a part of it, and that some minds are being opened up in the process, I...it doesn't truly bother me." (Interview 3). The most common themes associated with these positive comments were as follows (see Figure 11): everyone has a right to enter Wind Cave (9 people or 53\%); people should be allowed to enter provided that they learn about the Cave's cultural significance ( 5 people or $29 \%$ ); and being able to enter Wind Cave is an effective way to educate non-Lakota people about Lakota ways of life (3 people or $18 \%)$. One person (6\%) stated it is fine for people to enter Wind Cave because it is not technically a sacred site, but rather an origin site (which is different from the sacred site of a Sun Dance or vision quest).

(Interestingly, 4 people [24\%] made comments about the possibility that Wind Cave is not the actual site where Lakota people and the buffalo emerged onto the Earth as told in the Emergence Story; rather, it is the "accepted site" of such events.)

Eight out of 17 people interviewed (47\%) expressed negative thoughts or feelings about non-Lakota people entering Wind Cave (see Figure 10). All 8 of these people cited tourists' lack of respect for the cultural significance of Wind Cave as the primary reason behind their negative attitudes. The following quote is illustrative: "First of all, they're...they don't understand that they're going into - they don't realize that they're going into a sacred place. I mean.... For instance, if I see the non-Natives going into churches, maybe the Catholic church or something 
like this, and they go in in a reverent way. They bless themselves with the Holy Water and stuff like they go in, they kneel down and make the Sign of the Cross and they go in and they make a prayer. That's similar to what it should be to going down there, I think. Going in there in a respectable manner." (Interview 14).

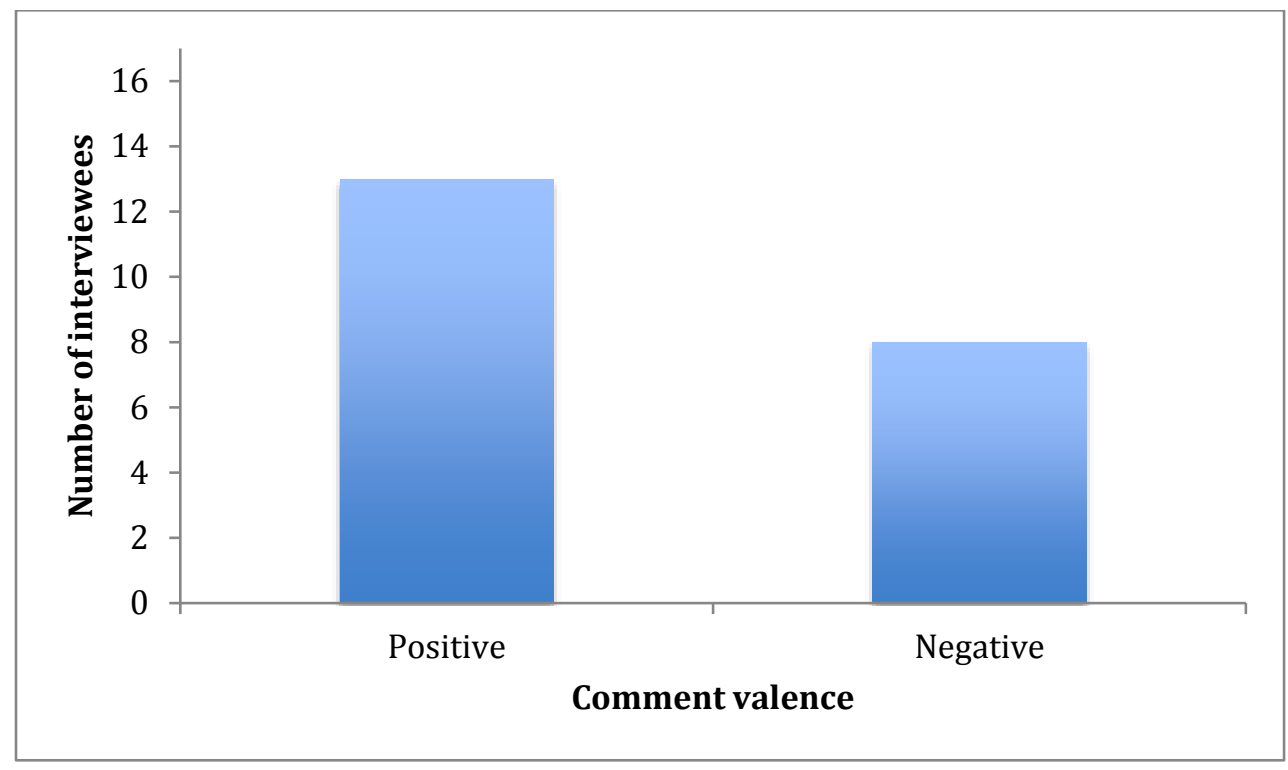

Figure 10. Number of interviewees who made positive or negative comments about non-Lakota people entering Wind Cave.

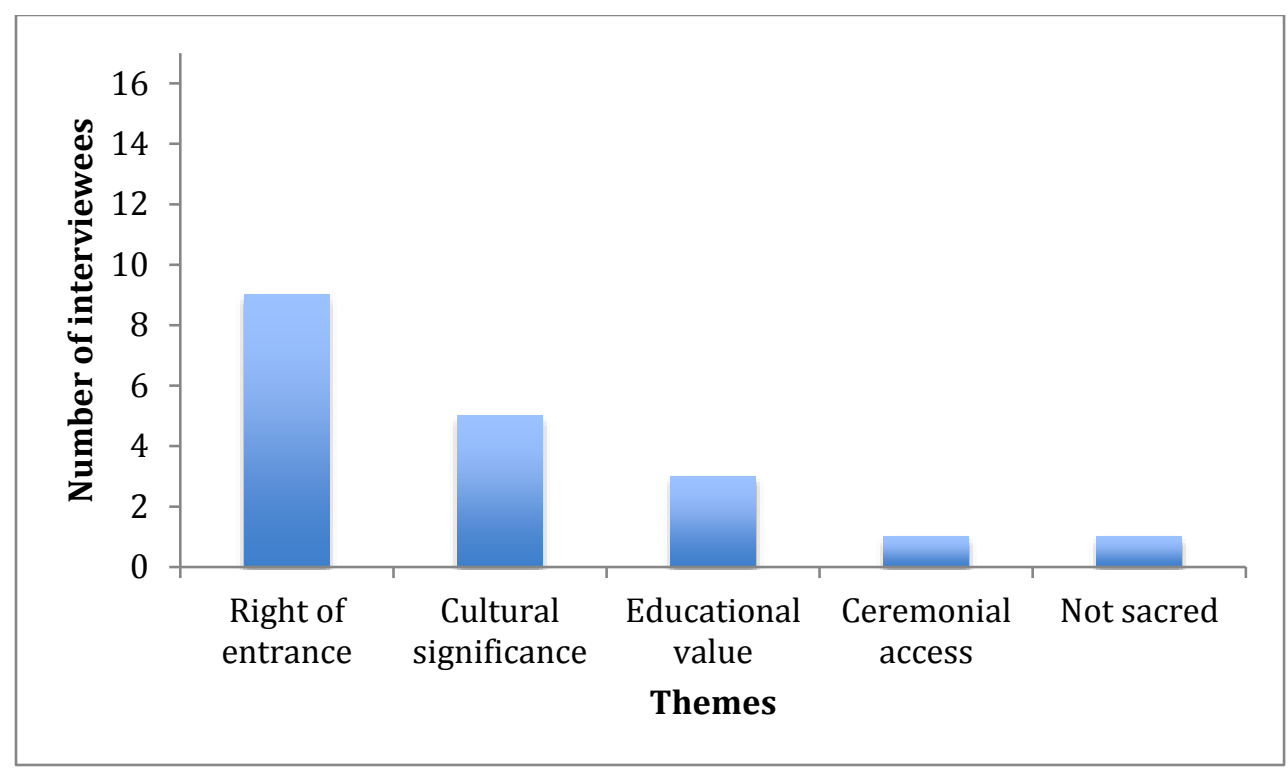

Figure 11. Most commonly reported positive comments about non-Lakota people entering Wind Cave. 


\section{Research Question \#4: Do the above attitudes differ depending on age?}

Of the 17 people interviewed, 9 of them (53\%) were under age 44 (“under"); the other 8 (47\%) were over the age of 44 (“over”). The extremely small sample size made it impossible to statistically analyze the two groups for significant differences in percentages based on age.

Therefore, the data were examined and those percentages that seemed significantly different are reported. Differences are reported for percentages reflecting attitudes addressed in RQs 1,2 , and 3.

One hundred percent of those under ( 9 out of 9) had positive comments about the Park; $75 \%$ of those over (6 out of 8 ) made such comments (see Figure 12). $67 \%$ of those under (6 out of 9) had negative comments about the Park; $100 \%$ of those over (8 out of 8 ) had such comments (see Figure 12).

One hundred percent of those under (9 out of 9) had positive comments about the interpretation at the Park; $13 \%$ of those over (1 out of 8 ) had such comments (see Figure 13.). All interviewees, regardless of age, made negative comments about the interpretation in general at the Park (see Figure 13).

$78 \%$ of those under ( 7 out of 9 ) had positive comments about non-Lakota people entering Wind Cave, and $75 \%$ of those over (6 out of 8 ) had such comments (see Figure 14). $44 \%$ of those under had negative comments about non-Lakota people entering Wind Cave, and $50 \%$ of those over (4 out of 8 ) had such comments (see Figure 14).

A few additional differences in the use of codes among older and younger people were noted. Those under were more likely to make comments about improvements at the park than those over (56\% of those under made such comments, compared to only $13 \%$ of those over). In similar fashion, $44 \%$ of those under stated that the park was willing to make positive changes; 
none of those over made such comments. One hundred percent of those under suggested that the park better emphasize the Emergence Story and Lakota perspectives of the park; only 63\% (5 out of 8) of those over made similar suggestions. (See below for more about suggestions.)

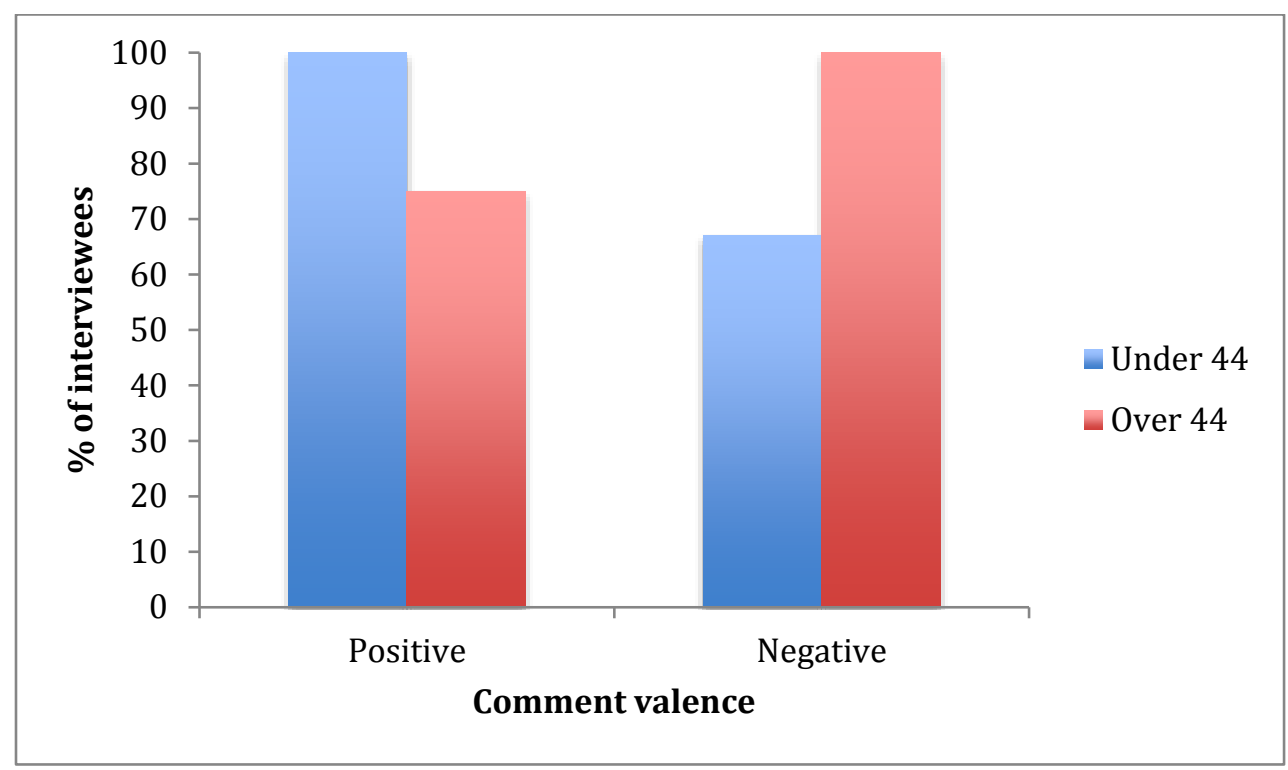

Figure 12. Percentages of those under age 44 and over age 44 who made positive and negative comments relating to Wind Cave National Park.

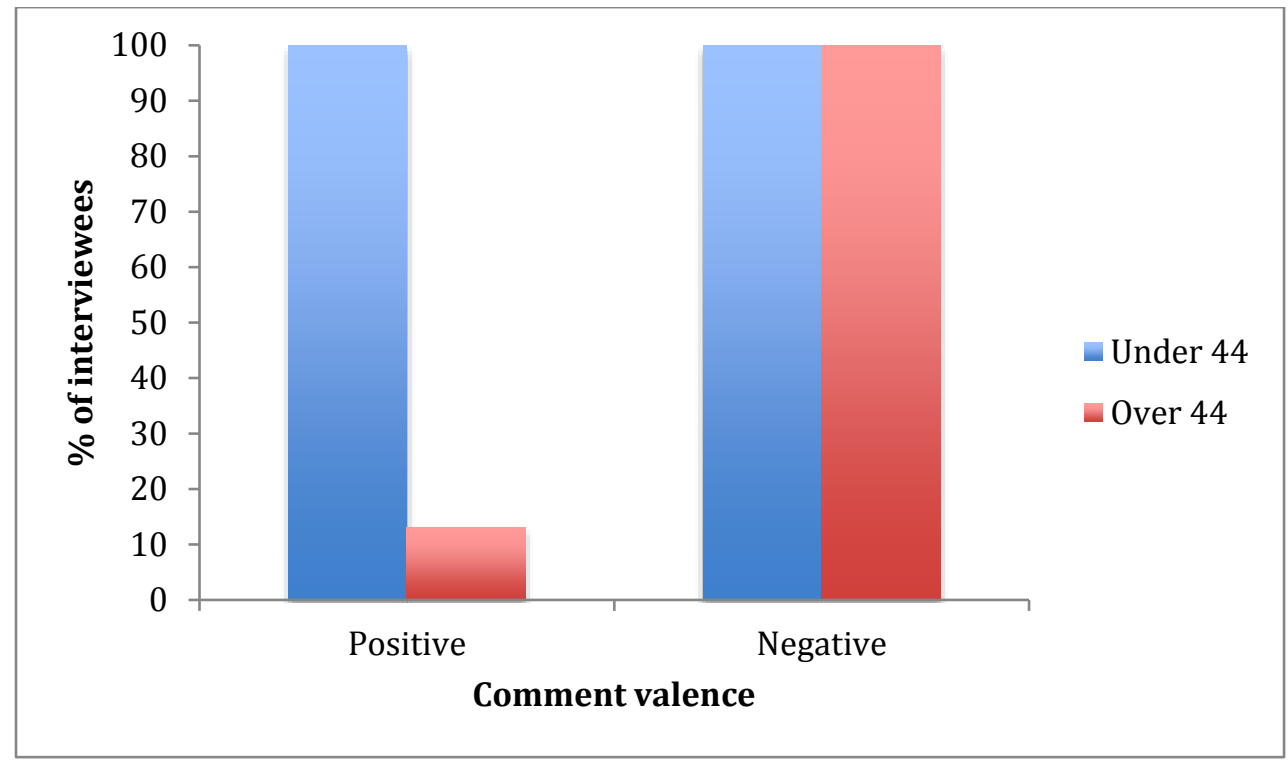

Figure 13. Percentages of those under age 44 and over age 44 who made positive and negative comments relating to the interpretation at Wind Cave National Park. 


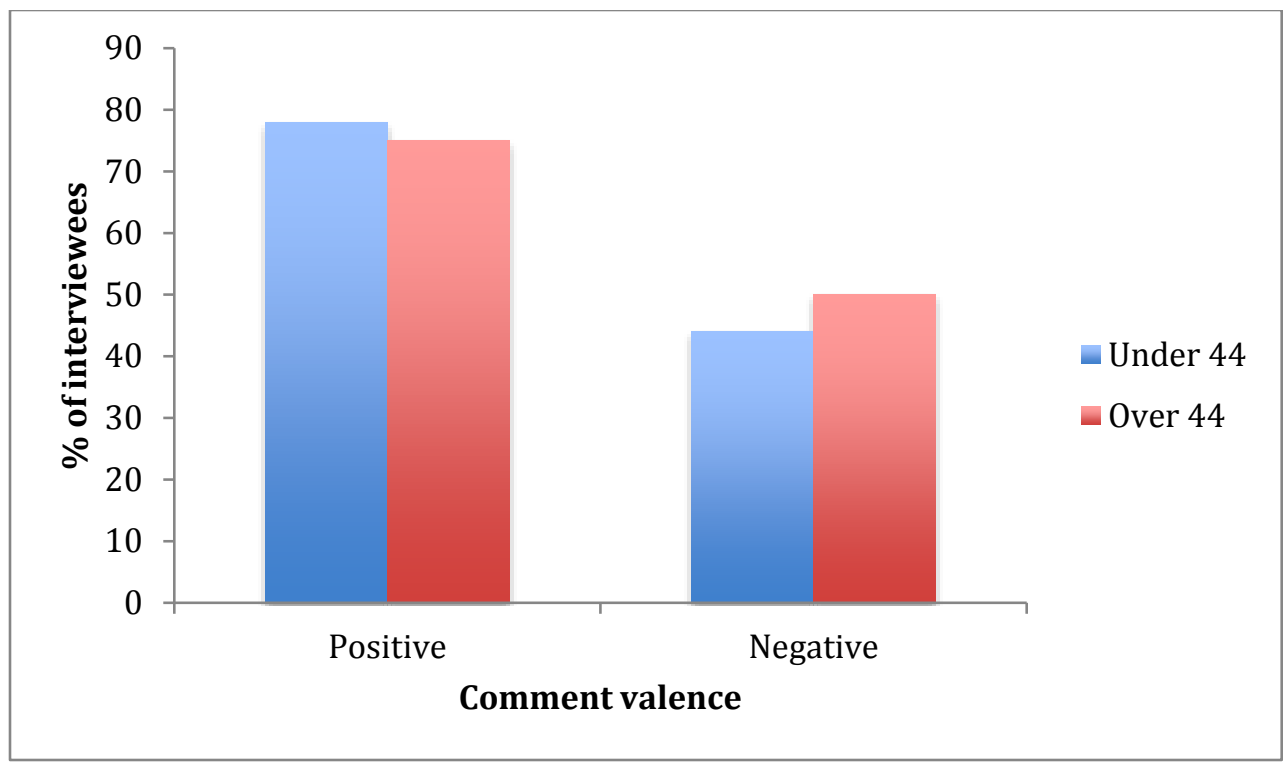

Figure 14. Percentages of those under age 44 and over age 44 who made positive and negative comments relating to non-Lakota people entering Wind Cave.

\section{Other Codes}

In addition to the attitude statements concerning RQs 1-4, interviewees made comments that generated codes in two additional categories: comments concerning the significance of Wind Cave to Lakota people, and suggestions given for improvements at Wind Cave National Park.

\section{Significance of Wind Cave}

Fifteen out of 17 people interviewed (88\%) made reference to the Lakota Emergence Story when talking about the importance of Wind Cave, as in the following example: "I think that, you know, it gives us a physical place where we as Lakota people can say, 'This is where we began, this is where our ancestors and where our-our culture, our belief system, our religious... this is where we believe that we are spiritually connected to this site." (Interview 12).

One person (6\%) specifically mentioned that Spirits could still be residing in Wind Cave, contributing to its significance. Two people (12\%) spoke of fond memories of time spent at Wind Cave contributing to its significance in their lives. 


\section{Suggestions}

Sixteen out of 17 people interviewed (94\%) made suggestions for improvements at Wind Cave National Park. Fourteen people (82\%) said that Wind Cave National Park needs to better emphasize the importance of Wind Cave to Lakota people; 3 of these people (18\%) specifically mentioned that the Park should invite Lakota elders to come to the Park to enhance interpretation. Six people (35\%) suggested that the Park make more of an effort to hire Lakota staff members. Four people (24\%) said that the Park should include perspectives from all 7 bands of Lakotas and/or from other tribes (e.g. Cheyenne, Arapaho) besides Lakota (they believe that currently any indigenous perspectives included in interpretation reflect exclusively those of the Oglala Lakotas). One person (6\%) felt that the park should make more of an effort to emphasize and interpret other resources in the park besides Wind Cave. One person $(6 \%)$ thought that the park should change its advertising strategy. 


\section{Chapter 5: Discussion}

\section{Complex Attitudes}

To say that the feelings of Lakota people toward Wind Cave National Park are complex is, if anything, an understatement. All but two interviewees (88\%) made both positive and negative comments during interviews, and several people specifically stated that their thoughts and feelings about the park were mixed or complicated. This should come as no surprise. Given the complex, controversial, and still very real and unsettled history concerning the U.S.

Government's seizure of the Black Hills from the Lakotas, it makes sense that any attitudes held towards a government-run park located in this area should be anything but straightforward.

Furthermore, it is important to keep in mind that even with a sample size as small as seventeen, which is by no means representative or comprehensive, the people interviewed varied widely in their opinions held about the park. On one end of the spectrum, two people had only negative comments during their interviews. Alternatively, although all seventeen people had at least one negative comment, two people had only a single negative statement, and six people had more positive than negative comments. This supports findings from the results of other studies concerning attitudes of members of an indigenous group towards a protected area (Infield, 1988; Allendorf, 1999; Anthony, 2007).

As with any group of people, not everyone who is a member of that group will think the same way, and the Lakotas are no exception. Although some may consider this a point that goes without saying, the results of this study warrant its mention. Too often throughout the history of the United States and continuing today, the values, attitudes, and beliefs of one or a select few prominent tribal members are improperly applied by non-indigenous people to be representative of the entire tribe (Ostler, 2010; Canby, 2015). One interviewee specifically mentioned this very 
problem when discussing indigenous people in the United States and their relationship with the National Park Service. It is therefore appropriate to mention that although tribal names have sometimes been used in the singular form to refer to every member of the tribe (e.g. "The Lakota believe that..."), this document purposefully refers to either the Lakotas or the Lakota people.

\section{Positive Themes}

Given the difficult history of the United States forcing the Lakotas off their land, the legacies of which are still apparent today on severely impoverished reservations like Pine Ridge, the high amount of positive comments made about the park may come as a surprise. On one hand, the National Park Service, as part of the Department of the Interior, represents the United States federal government, which violated the terms of the 1868 Fort Laramie Treaty when it illegally seized the Black Hills from the Lakotas. But on the other hand, the National Park Service stands for preservation, a concept that is highly compatible with traditional Lakota spirituality and values. Indeed, well over half the interviewees mentioned the fact that the park is preserving Wind Cave, the aboveground mixed-grass prairie, and/or the wildlife it supports.

Preservation. The theme of preservation is consistent not only with the values of traditional Lakota viewpoints, but with those of many groups of indigenous people across North America and the globe. This theme has been salient in a few of the more prominent protected area/indigenous group conflicts in the United States: the unsuccessful attempt of several California tribes to prevent construction of a logging road through Six Rivers National Forest (Canby, 2015); the self-imposed fishing ban of the Red Lake Band of Chippewa to restore the walleye population in Red Lake (Record, 2012); the opposition to building a ski resort in the San Francisco Peaks (Canby, 2015); and the current resistance to the construction of the Dakota Access pipeline near the Standing Rock Reservation in North Dakota (Liu, 2016). The fact that 
these examples of environmental degradation were also opposed on religious grounds should not be surprising; for many indigenous cultures, the practice of their traditional religion/culture and the natural environment are often inextricably linked (Canby 2015).

Positive Change. Another positive trend of note from the results of the present study is the fact that three people separately mentioned that Wind Cave National Park is willing to make positive changes. Despite the many critiques of the interpretation at Wind Cave, the park should be reassured to know that at least a portion of Lakota people are optimistic about where the park is headed. This is especially important to consider as the park prepares to replace its visitor center exhibits in the coming years.

Entrance Attitudes. Research Question 3, which dealt with Lakotas' attitudes about non-indigenous people entering Wind Cave on cave tours, was notably met with primarily positive comments (Figure 10). However, not all responses were positive. As one person said straightforwardly, "I would close the whole thing down. Move 'em out." (Interview 14). But most of those interviewed mentioned that people should have a right to enter the cave; many shared the following interviewee's sentiment: "I think that these places are important for all people to experience." (Interview 12). "I think it's beautiful to share something so sacred to us, " (Interview 10) said another. Several people also mentioned its potential educational value. The cave could serve as an important resource that can aid Lakotas in teaching about their traditional cultural values to a largely non-indigenous audience. The main problem most interviewees had with non-indigenous people entering the cave was that tourists do not have proper respect for the sacredness of the area. As one interviewee put it, "We consider these places to be sacred, right? And so-when I go into a church, or when I go into a cathedral, or when I go into a mosque, or someplace where-that other people consider to be sacred, or, you 
know, an important place, I conduct myself accordingly. I don't scream around, I don't yell, I don't run, I don't bump into things. ...I act respectfully. Because that is a sacred place." (Interview 8).

However, the root of the problem may not be that people are intentionally disrespectful, but rather that they do not know that they should be respectful. That is to say, they may not know that the cave is sacred in the first place. A theme that was ubiquitous among the 17 interviews was the need to better emphasize Lakota cultural perspectives at Wind Cave National Park (see below). Therefore, the true root problem is that the park does not adequately prepare people to enter the cave. The park's inability to communicate the cultural significance of the cave prior to tours may then be the underlying cause of most negative comments directed at nonindigenous entrance into the cave.

The fact that those interviewed are generally very open to what may be seen as outsiders intruding on a sacred space may come as a surprise to many. This is very different from the case of Chief Mountain in Glacier National Park (Keller \& Turek, 1998). Several plains tribes regard the peak as sacred, and asked the NPS to curtail non-Indian access (Keller \& Turek, 1998). (The tribes were denied their request (Keller \& Turek, 1998).) In other cases, the NPS does restrict access to sacred sites. In Grand Canyon National Park, the NPS discourages hikers from visiting Sipapu, were Hopi people believe they entered the world (Keller \& Turek, 1998). Also at Grand Canyon, the Colorado salt mines, another sacred site for the Hopi people, are off-limits for nontribal visitors (Keller \& Turek, 1998).

Despite this, indigenous openness to non-indigenous intrusion is actually not all that uncommon a finding. Similar to the controversies surrounding the Arizona Snowbowl Ski Resort in the San Francisco Peaks (Mahoney, 2011) and Devils Tower National Monument 
(Dustin et al., 2002), most members of indigenous groups do not necessarily object to any intrusion of non-indigenous people into these sacred areas per se; rather, they object to such intrusions that result in the unacceptable desecration of that sacred site (i.e., rock climbing on Mato Tipila (Devils Tower) or construction of a ski resort and use of sewage water to make artificial snow in the San Francisco Peaks).

Among Lakota sacred sites, the predominant view found in the present study is consistent with the aforementioned Mato Tipila and Mato Paha (Bear Butte State Park). On the other hand, many other Lakota sacred sites that are not known to non-indigenous people are kept "hushhush" (Interview 12) so as to prevent intrusion by non-indigenous people. This may be explained by the fact that these sites are kept more carefully guarded due to the fact that are not known to non-indigenous people. Wind Cave National Park, Devils Tower National Monument, and Bear Butte State Park are all well-known tourist attractions that see thousands of nonindigenous visits each year, and so would be impossible to protect in the same way as those sites that are yet unknown to non-indigenous people.

Although Lakotas have many names for Wind Cave, including Makoce Ohloka, Wasun Wiconiya Wakan, Washun Niye, Maka Oniye, and Pte Kinapapi, no one who was interviewed mentioned anything about changing the name of Wind Cave National Park, or expressed any dissatisfaction with the name. Although this is consistent with the findings of this study concerning entrance attitudes, it stands in stark contrast to the experiences of other NPS sites. The site of the Battle of the Little Bighorn or "Custer's Last Stand" in Montana (which indigenous tribes refer to as the Battle of the Greasy Grass, among other names (McCabe, 2014)) was known as Custer Battlefield National Monument until 1991 (The New York Times, 1991). In that year Congress passed a bill that authorized the construction of a memorial to the 
indigenous people who fought and died in the 1876 battle, and renamed the site as Little Bighorn Battlefield National Monument (The New York Times, 1991). Likewise, the name Devils Tower is supposedly due to a misinterpretation of an indigenous name for the butte (NPS, 2017c); this is not the tribal members' name (J. Bruce, pers. comm., 2/26/17). The name is still "highly contested" by indigenous peoples (J. Bruce, pers. comm., 2/26/17).

\section{Negative Themes}

Despite the large amount of positive comments made by those interviewed, negative comments far outweighed the positive ones. Every interviewee had at least one negative comment, and two interviewees expressed exclusively negative comments. This negativity is most pronounced in regards to RQ2, which deals with the interpretation of the park. When only considering broad comments made about the park that did not directly relate to interpretation, there were actually more people with positive comments (15) than negative (14) (Figure 1). But comments directly associated with interpretation tended to be negative (Figure 4), particularly those associated with the visitor center exhibits (Figure 8). Only 3 people had positive comments about the exhibits, compared to 12 who had critiques.

Lakota Neglect. The pervading negative theme of many interviews was a lack of Native voice, which is reflected in the results. Ten people stated that the visitor center exhibits neglect Lakota perspectives of Wind Cave (Figure 9) and 9 people had the same concern about cave tours (Figure 7). Even among comments that were not directed toward interpretation but rather to Wind Cave National Park in a broader sense, neglect of Lakota perspectives was the secondmost frequently used code category, having been mentioned in 8 interviews (Figure 3). One interviewee summed up the problem quite simply: "I was looking around there, and I...made remarks about...hey, this is Native American, and there's nothing that exists in there pertaining 
to Native Americans" (Interview 14). Some even felt that this was purposeful on the part of the park (Figures 3, 7, 9).

Of particular concern to many interviewees was the language and historical starting point of the exhibits. "You would think that time began in 1881 and nothing ever happened before that point," (Interview 11) stated one individual. “...With the way they balance the exhibits, they are telling people that [indigenous] history is not as important [as Euro-American history]."

Several made similar comments about the history the visitor center exhibits acknowledge, that of Euro-American discovery and exploration of Wind Cave, while almost entirely neglecting other sides of history, namely the extensive history of indigenous peoples' interaction with and relationship to the many natural resources (Wind Cave, The Racetrack, the mixed-grass prairie and its associated wildlife) that are protected by the park. As one person said: "I think the tone is dismissive. ...A white man found it, so a white man exploited it, so a white man-and we talk about this.... So I think the overarching goal is to diminish any existence of any of the cave until a white man discovered it." (Interview 17). Another interviewee offered a simple yet poignant reflection on the historical content of the exhibits: "History is written by the winners of wars." (Interview 8).

Tourist Attraction. Besides the pervasive theme of inadequate Lakota representation at Wind Cave National Park, other negative themes surfaced during the interviews. Nine respondents viewed the fact that Wind Cave is a tourist attraction in a negative light (Figure 3). This stands contrary to positive comments concerning the fact that the National Park protects the valuable resources of the cave and the prairie. Some interviewees who made negative tourist attraction comments qualified their statements, adding that Wind Cave was much more acceptable than other show caves in the Black Hills, such as Rushmore Cave, Wonderland Cave, 
Black Hills Caverns, and Sitting Bull Crystal Caverns (now closed). These caves are all privately owned and are much more "commercialized" than both Wind Cave and Jewel Cave, which are operated by the National Park Service.

The juxtaposition of positive comments about preservation and negative comments about tourism may best be understood in the light of the mixed feelings that most interviewees held toward the park in general. Whereas they are glad Wind Cave is not the same type of blatantly profit-oriented operation that other private show caves in the region are, many of those interviewed are still disappointed that their sacred site is another site-seeing stop for many a family's vacation to the Black Hills. Complaints of well-loved sites becoming too commercialized or "touristy" are not uncommon and are by no means unique to sacred sites (Runte, 1997; Mabunda \& Wilson, 2009), and may well be related to literature on crowding and cultural carrying capacity (Wagar, 1964; Manning \& Lime, 1996; Arnberger \& Brandenburg, 2007).

Fees. Another negative theme that may be of particular concern for the park is that of fees. Five interviewees complained about having to pay a cave tour fee to gain access to Wind Cave (Figure 3). However, this viewpoint is inaccurate, as any registered member of any federally-recognized Lakota tribe can obtain a cave tour ticket for no charge. The park recognizes 21 federally-recognized tribes as having historical ties to Wind Cave, and any member of these tribes who presents his tribal ID can obtain a cave tour ticket. Furthermore, the park grants ceremonial access to those who wish to conduct ceremonies or hold other religious observances. The fact that several people were unaware of these policies indicates that the park does not sufficiently advertise them or make them known. A seemingly easy way for Wind Cave 
National Park to improve its perception among Lakotas would be to make clearer their policies about Lakotas' access.

Treaty Violation. The Fort Laramie Treaty of 1868 that created the Great Sioux Reservation (which contained all land in South Dakota lying west of the Missouri River, including the Black Hills) is still a point of contention among many Lakotas today (Ostler, 2010). They hold that the expedition led by Lieutenant General George Armstrong Custer in 1874 that claimed to have confirmed the presence of gold in the Hills, and the United States' subsequent seizure of the Hills in 1876-77, were direct violations of the treaty (Ostler, 2010). Ultimately, many $21^{\text {st }}$ century Lakotas believe that the Black Hills should rightfully belong to them (Ostler, 2010), and therefore a United States National Park in the area would be viewed as an unacceptable intrusion (Ostler, 2010). The fact that four people mentioned the park being a violation of the treaty should therefore not come as a surprise; 4 out of 17 is even lower than what might reasonably be expected. Words like the following can give the park hope for a positive future: "I really do have the attitude...that what happened in the past...I mean, it's already done. And you can sit around feeling bitter about that, or you can work to make changes.” (Interview 11). But other people had strong words concerning the relationship between indigenous groups and the National Park Service: “...the entire [NPS] needs to be made aware of the fact that number one, as to native cultures, to indigenous cultures, they are intruders. They are guests.... And to remember that you're not welcome guests to begin with." (Interview 17). Such words should serve as a strong reminder that the Black Hills land claim dispute is not something that is likely to go away in the near future; it is simply a reality the park will have to be cognizant of going forward as it works to make those positive changes mentioned in the first excerpt above. 
The international trend towards co-management of protected areas has purportedly been the goal of the southern unit of nearby Badlands National Park (Rights and Resources Initiative, 2015). Wind Cave National Park was not created to be co-managed (Spence, 2011), and despite efforts like the Bradley Bill (Worster, 1992; Ostler, 2011), it likely will not become co-managed, at least in the foreseeable future. Given the history of the land claim dispute, particularly in light of the aforementioned co-management trend, it should come as no surprise that Lakotas are upset with regards to the Fort Laramie Treaty of 1868. This provides as yet another reason why collaboration with local tribes is vitally important for Wind Cave National Park (Albers, 2003; Tuxill et al., 2009).

\section{Differences Based on Age}

Research Question 4 compared responses between those under and over the age of 44 (the average life expectancy of a male on the Pine Ridge Reservation) (American Indian Humanitarian Foundation, 2014). It seems that younger people hold more positive attitudes toward the park than older people. As Figure 12 shows, younger people were more likely to make positive comments about the park and less likely to make negative comments. And it is noticeable in Figure 13 that every interviewee under the age of 44 made a positive comment about park interpretation, whereas very few of those older than 44 made any such comments. The exception to younger people holding more positive attitudes is shown in Figure 14. It seems that older and younger people do not differ with respect to their attitudes towards non-Lakota people entering Wind Cave.

\section{Recommendations and Implications}

Patricia Albers' 2003 study of Wind Cave National Park produced several recommendations, one of which was to build and maintain positive relationships with local 
tribes. To be sure, there are several signs that the park has improved its relationship with Lakota tribes over the last fourteen years. In 2003, there was practically no indication that Wind Cave had any significance beyond its geologic value. A sign placed at the natural entrance to the cave informed visitors that two white men, Tom and Jesse Bingham, where hunting in 1881 when they discovered the mysterious hole in the ground that blew air. Today, a different sign in its place gives visitors a brief overview of the Lakota Emergence Story. The sign was a collaborative effort among several Lakota tribes.

In the summer of 2014, the park hired their first Lakota person to work as a seasonal interpretive ranger (S. Bear Eagle, pers. comm., 7/29/16). Seasonal rangers now receive training concerning Lakota perspectives of Wind Cave; they are expected to inform visitors about the spiritual significance of Wind Cave, including at least a brief overview of the Emergence Story, during their tours. A site bulletin (pamphlet) that tells one version of the Emergence Story is also available in the visitor center.

Despite these positive steps, it is clear from the results of the present study that Wind Cave National Park has a long way to go to include a proper representation of Lakota perspectives in their interpretation. Albers (2003) stated that the park needs to build and maintain positive relationships with local tribes, and this is just as true today as it was when she conducted her study. Albers' recommendation and that being made in the present study echo the participatory planning movement that has been emphasized in the National Park Service over the past twenty years (Steelman, 2001; Burby, 2003; Brown and Weber, 2011). The NPS' very own Stronger Together publication stressed the importance of collaborative planning with key stakeholders (Tuxill et al., 2009), which in the case of Wind Cave certainly includes local indigenous tribes. One passage in Stronger Together speaks directly to sites that may have a 
"difficult history": "developing a working relationship will allow staff to explore common concerns, which may help defuse tension at some future time" (Tuxill et al., 2009, p. 26).

It is clear that the park must build a stronger relationship with these tribes, and none are more local than the Oglala Lakotas on the Pine Ridge Indian Reservation. Albers went on to state that involving tribal members in the development of park interpretive narratives is fundamental. The Emergence Story site bulletin is a positive step, but many more need to be taken. Figures 3, 7, and 9 clearly indicate that Lakotas interviewed in this study feel their voice is not adequately represented at Wind Cave National Park. This neglect can contribute to an unwelcoming feeling for Lakota people: “There's an atmosphere [at Wind Cave National Park]_an atmosphere that Lakota people don't necessarily feel welcome...” (Interview 11).

It should be pointed out that the lack of communication between the park and local indigenous tribes may not, and probably is not, entirely due to the fault of the park. Effective communication requires that all parties be willing to participate, and there are almost certainly shortcomings on both sides. However, this does not in any way relieve the park from attempting to "foster and maintain good collegial relations with the local populations whose own histories and traditions are represented in [the park's] resources" (Albers, 2003, p. 650). Albers also states that the park "will need to solicit advice beyond the offices of tribal government and call on tribal educators and religious practitioners for inspiration and direction. Above all, the [Park Service] should not rely on lone advisors and consultants" (Albers, 2003, p. 651).

In the immediate future, because they are developed by individual seasonal employees and are not physically permanent like exhibits, it will be easier to incorporate proper cultural perspectives on cave tours (Ham, 1992). Positive change has taken place on cave tours over the last couple years, and this is reflected in the results of this study. Many more people made 
positive comments about cave tours (8) than visitor center exhibits (3), and one interviewee even specifically mentioned that tours were improving. The park should make clear during its training of interpretive rangers the importance of emphasizing the cultural significance of Wind Cave, particularly the Emergence Story, to visitors on cave tours. Speaking in regards to the Emergence Story, one interviewee stated, “This Story is just as important [as] any [other] story that they're telling. So it's not something that should be glossed over; it's not a footnote" (Interview 11). One Lakota person offered the recommendation that rangers should divide their tours equally between interpretation of scientific and cultural perspectives. Inviting Lakotas to come and speak to interpretive rangers during training would be another way to build connections to tribal members, as well as expose interpreters to indigenous perspectives.

At nearby Devils Tower National Monument, the sacred indigenous narratives associated with the rock formation are "at the center" of interpretive efforts regarding indigenous peoples (J. Bruce, pers. comm., 2/26/17). Wind Cave should make a similar effort to make the Emergence Story the central focus of indigenous interpretation. According to the education ranger at Devils Tower, such traditional stories can serve as a starting point from which to make connections to current issues: "the cultural stories allow us to shift the focus from past to present" (J. Bruce, pers. comm., 2/26/17). Thus, emphasizing the Emergence Story could allow Wind Cave to further explore more current topics related to the Lakotas and other tribes.

Despite the generally negative comments about personal interpretation at Wind Cave National Park, it seems as though cave tours are not all that far away from being excellent in regards to Lakota inclusiveness. The malleable nature of tours makes it relatively easy to make proper changes and improvements (Ham, 1992). If the importance of emphasizing cultural perspectives is made clear to seasonal rangers, it is reasonable to expect that tours of Wind Cave 
can be inclusive and respectful towards Lakotas and other indigenous people in the very near future.

The state of the visitor center exhibits, on the other hand, provides less reason for optimism. Those interviewed expressed stronger negativity towards the exhibits (Figure 8) than towards cave tours (Figure 5). The permanent nature of exhibits makes it much more difficult to easily incorporate indigenous perspectives into this non-personal interpretation without completely replacing the entire system of exhibits. It should be noted that such a problem is hardly unique to Wind Cave. Even at Devils Tower, exhibits only share "small bits" about historical connections to indigenous people, and many NPS employees themselves feel that the Visitor Center "has a lot of room for improvement" (J. Bruce, pers. comm., 2/26/17). Likewise, Apostle Islands National Lakeshore, which has cultural ties to the Ojibwa (or Chippewa) people, largely ignored Ojibwa history in its interpretation for its first 30 years of existence (Keller \& Turek, 1998). More recently, the lakeshore has been working to integrate Ojibwe "culture, history, and language into the entire spectrum of...interpretation and education at Apostles," although "most of this is completed through direct visitor programming" (D. Panek, pers. comm., 3/17/17). Mount Rainier National Park, in Washington State, also neglects to inform visitors why they might come upon places named Yakima Park, Indian Bar, or Ohanapecosh Creek in the Park (Keller \& Turek, 1998).

Fortunately, replacement of exhibits at Wind Cave is planned in the not-to-distant future. In the meantime, it is recommended that the park do what it can to incorporate Lakota and other indigenous perspectives into its non-personal interpretation in whatever ways possible. The historical timeline in the basement was of particular concern to many interviewees; it was singled out by many as being an archetype of Lakota neglect in the visitor center. This timeline could be 
changed to include an idea of the spiritual significance of Wind Cave to Lakotas and other indigenous people. Important events in the Black Hills land claim controversy could also be noted on the timeline. This would be an interpretive improvement, as visitors would be presented with information about a contentious topic and left to come to their own conclusions. The concept of embracing controversy is often cited as a best practice in interpretation, and other parks are doing just that with their non-personal interpretive materials (e.g. Shenandoah National Park, Manzanar National Historic Site, and Antietam National Battlefield) (Whisnant et al., 2011). Furthermore, it would help place the park's historical narrative in larger historical and geographic contexts.

The language of exhibits is another concern voiced by several interviewees. For example, referring to the time before 1881 as "Prehistory" on the timeline could perpetuate the harmful idea that all indigenous peoples were uncivilized, and could only be properly enlightened by the culturally superior white man. This is something the park will need to take very seriously and pay close attention to when the wording for the new exhibits is chosen. But in the meantime, it is possible that such words on current exhibits could be covered with more appropriate terms or deleted.

The Emergence Story site bulletin is a positive step forward and indicates an opportunity to increase Native voice in the visitor center's non-personal interpretation outside of the permanent exhibits. Site bulletins are available by request at the front desk. They cover a wide range of topics germane to the park, and other bulletins dealing with indigenous perspectives could be developed. The topics of such bulletins might include the spiritual significance of Wind Cave to various tribes, the significance of the bison (or buffalo) and other park wildlife to indigenous peoples, indigenous uses of various plants and herbs (ethnobotany), the story of the 
Great Race (concerning the Racetrack or Red Valley in the park), and/or a synopsis of the Black Hills land claim controversy, among other ideas.

Another suggestion made by multiple interviewees was for the park to further develop its interpretation of so-called "surface" resources, or those above the ground, that are relevant to indigenous people. The Racetrack or Red Valley, which plays a prominent role in another traditional Lakota story, runs through the park, and the Buffalo Gap, although located outside park boundaries, can be viewed from within the park. Furthermore, many plants of the mixedgrass prairie were of importance to the Lakotas and other tribes in the region for medicinal and other purposes. One interviewee suggested that the park develop an ethnobotany walking tour. And of course, the protection of wildlife in the park, particularly of the bison (or buffalo), lends itself to interpretation focused on the relationship held between these animals and the Lakotas and other indigenous peoples.

Several interviewees suggested that the park hire more Lakota staff members. In the summer of 2014, Wind Cave hired a full-time summer seasonal ranger who is Lakota; she remains the only staff member who is Lakota. Other NPS units with important indigenous cultural ties, such as Little Bighorn Battlefield National Monument, have a mix of both native and nonnative interpreters on staff (G. Jasmer, pers. comm., 2/25/17). Devils Tower has had two native superintendents since 2006 (N. Stinson, pers. comm., 3/10/17). The most well-known native NPS superintendent must be Gerard Baker, thanks to his feature in Ken Burns' film The National Parks: America's Best Idea. Baker is responsible for many of the progressive changes that took place at Little Bighorn Battlefield National Monument (Burns \& Duncan, 2009). He then served as the first superintendent of the Lewis and Clark National Trail, before becoming superintendent of Mount Rushmore National Memorial, a position from which he retired in 2010 
(Claymore, 2010). Wind Cave can also take inspiration from Olympic National Park, which in August of 1991 signed a 5-year job-training agreement with several local tribes, with the aim of attracting more tribal members to NPS careers (Keller \& Turek, 1998). This program was similar to one started at Canada’s Pukaskwa National Park (Keller \& Turek, 1998).

However, other sites with indigenous cultural ties struggle to hire Native employees. Glacier National Park, for example, which is made up of land formerly belonging to the Blackfeet tribe, has hired few Blackfeet rangers (Keller \& Turik, 1998).

Many interviewees also suggested that the park bring in Lakotas and other indigenous people to present programs about cultural topics. Wind Cave can follow the lead of other NPS sites that already have programs in place for inviting tribal members to participate in park interpretation. Agate Fossil Beds National Monument, located in the nearby Nebraska panhandle, has a cultural demonstrator program (NPS, 2017a). Indigenous artists set up shop in the visitor center during summer weekends, where they can share their artwork and stories as well as sell pieces to the public (NPS, 2017a). Tribal members play a key role at Little Bighorn Battlefield around the time of the anniversary of the well-known battle between several indigenous tribes (including Lakotas), and the U.S. Army's $7^{\text {th }}$ Cavalry. During several days surrounding June 25-26, Lakota, Cheyenne, Arapaho, Crow, and Arikara tribal members present their own perspectives of the famous battle to park visitors (G. Jasmer, pers. comm., 2/25/17).

Little Bighorn also has a contract agreement with the Crow Nation, under which the Crow provide five daily bus tours of the battlefield (G. Jasmer, pers. comm., 2/25/17). It is not uncommon for NPS sites to maintain agreements with tour/guide companies; according to the law firm Van Ness Feldman, the NPS has over 500 contracts, 5,000 commercial use authorizations, and 150 leases with private businesses that offer visitor services (Van Ness 
Feldman LLP, 2017). Although it may not be realistic for Wind Cave to pursue such a formal agreement in with the Oglala Sioux Tribe or other Lakota tribes in the immediate future, it is a promising option for the future and a goal towards which the park could work in the coming years. The addition of the Sanson Ranch property, which includes tipi rings and a possible buffalo jump, especially lends itself to Native interpretation. (It should be noted that Little Bighorn Battlefield National Monument, unlike Wind Cave National Park, is located entirely on a reservation, in this case the Crow Indian Reservation.)

Wind Cave, however, does not need to rely on other parks for examples of indigenous cultural presentations; in 1937, Wind Cave National Park itself maintained an Indian camp and exhibit (Ostler, 2010). The camp was almost certainly an appropriation of indigenous culture, similar to what took place at Glacier National Park with the Blackfeet (although not of the same magnitude) (Keller \& Turek, 1998), and such an unmodified recreation may be inappropriate in the $21^{\text {st }}$ century. Nonetheless, the camp provided many benefits for Lakotas. Besides being a source of much-needed income, Lakotas were able to educate non-indigenous visitors and their own youth about their way of life; they were also permitted to procure medicinal plants and harvest lodgepole pines in the park (Ostler, 2010). It will be critical for the park to consult with indigenous tribes before considering anything of this nature. Nevertheless, it shows that the park has at least attempted to represent indigenous culture in the past. Managers can call upon such a precedent when considering presentations focused on indigenous culture.

\section{Limitations}

There are several limitations of this study that warrant mention. Methodologically, the practice of chain sampling carries with it some inherent limitations (Biernacki and Waldorf, 1981; Sadler et al., 2010). Foremost is the fact that the sample used for this study is not 
representative of the population. Since it is composed of just seventeen individuals, it is not large enough for any serious statistical analysis. And although the original intention was to include in the sample individuals who grew up off of any reservation, only two people out of seventeen grew up exclusively off-reservation. Almost half of the members of the Oglala Sioux Tribe live off of Pine Ridge Reservation (South Dakota Department of Tribal Relations, 2011), and this group was not adequately represented in the sample for this study. The major cause of this sampling problem was lack of time. All interviews were conducted within a three-month period, and the comparatively limited accessibility of the population made it difficult to attain an adequate sample in such a short time period.

Because of the unrepresentative sample, the study is not generalizable to any other population or situation. However, as a qualitative study, the goal was not to generalize but rather to arrive at a better understanding of the subject. Future quantitative studies might aim to generalize based on a representative sample.

\section{Conclusion}

Wind Cave National Park, located in the southern Black Hills of South Dakota, is contested terrain. A national park since 1903, Wind Cave protects what many Lakotas and other indigenous people accept as the site of the Emergence Story, where humans first populated the earth. Many indigenous people regard the entire Black Hills as sacred, and the Hills have similarly been the subject of a land claim controversy for nearly 150 years. The complex history of the park, the surrounding land, and the relationship between the federal government and the Lakotas and other indigenous peoples of this country make it imperative for the park to understand the attitudes of these peoples towards the park today. Following recommendations from Albers (2003) and the NPS' own Stronger Together (Tuxill et al., 2009), park staff, 
throughout all aspects of planning and management, should collaborate closely with local indigenous tribes that have cultural connections to the park's resources. This is the first study that attempts to characterize the attitudes of some Lakota people towards Wind Cave National Park.

In this study, seventeen interviews were conducted with Lakota people during the summer of 2016 in the Black Hills. Because of the sensitive nature of this study and the relative inaccessibility of the population, an initial snowball or chain sampling approach was first employed, whereby each interviewee referred the interviewer to other potential participants. Additionally, a criterion sampling approach was also used based on age, in order to assess differences in attitudes between younger and older interviewees. The interview transcripts were analyzed using a content analysis approach. Some coding categories were determined a priori, but most emerged during the coding process after the interviews had taken place.

Several major positive and negative themes emerged during analysis. Despite decidedly complex and mixed attitudes towards the park, the most frequently occurring theme was that interviewees were unhappy with the apparent neglect of Lakota cultural perspectives in Wind Cave's interpretation. The interviewees believed the park needs to include more Native voice. Interviewees also had negative attitudes concerning entrance fees for cave tours, the touristattraction nature of a sacred site (i.e. Wind Cave), and the violation of the Fort Laramie Treaty of 1868 (which granted Lakotas rights to the Black Hills). But not all themes were negative. Interviewees frequently expressed positive attitudes towards the preservation nature of the national park, they felt favorably toward non-indigenous people entering Wind Cave on cave tours, and several (young people especially) felt that the park's interpretation is improving. Younger interviewees also tended to make more positive comments than older interviewees. 
Wind Cave National Park is in the process of replacing the visitor center exhibits, and this presents a perfect opportunity to collaborate with local tribes to incorporate broader perspectives in the exhibits. Cultural perspectives on cave tours can also be better emphasized. The park should make an effort to hire more Lakota staff members, and should consider inviting tribal members to the park for guest presentations, as other NPS sites already do. 


\section{Appendices}

\section{Appendix A: Interview instrument}

(Listed after each question is the Research Question each item seeks to answer. The Research Questions are re-listed below. "Rapport" indicates that the question simply seeks to build rapport between the interviewer and interviewee.)

RQ 1: What are the attitudes of Lakota people towards Wind Cave National Park?

RQ 2: What are the attitudes of Lakota people toward the National Park Service's interpretation of Wind Cave?

RQ2a: What are the attitudes of Lakota people towards the National Park Service's personal interpretation of Wind Cave, i.e. a cave tour?

RQ2b: What are the attitudes of Lakota people towards the National Park Service's nonpersonal interpretation of Wind Cave, i.e. exhibits in the visitor center?

RQ 3: What are the attitudes of Lakota people toward non-indigenous people entering Wind Cave?

RQ 4: Do the above attitudes differ depending on age?

Interview guide (inspired from Allendorf, 1999)

[Interviews started with general introductory questions focused on building rapport. Before starting with question 1 , interviewer asked for the age of each interviewee.]

1. How long have you lived here? (Rapport, RQ1a)

2. Where did you grow up? (RQ1b)

3. Are you familiar with Wind Cave National Park? (RQ1)

4. How familiar are you with the National Park? When was the last time you were there? How often do you visit? (RQ1, Rapport) 
5. What does Wind Cave mean to you? What is its significance? (Rapport)

6. What are your thoughts or feelings towards the park? (RQ1)

7. Have you been on a NPS ranger-led cave tour at Wind Cave? (RQ2a)

8. What are your thoughts or feelings about the tour? (RQ2a)

9. Have you spent time in the visitor center, view any exhibits, or notice any signage at the National Park? (RQ2b)

10. What are your thoughts or feelings about the visitor center, the exhibits, and/or the signage at the National Park? (RQ2b)

11. How do you feel about non-Lakota people entering Wind Cave? (RQ3) 


\section{Appendix B: a priori Coding Table}

\begin{tabular}{|c|c|}
\hline Parent codes & Child codes \\
\hline $\begin{array}{l}\text { Length of time interviewee } \\
\text { has lived in current location }\end{array}$ & \\
\hline Location where interviewee & On Pine Ridge Reservation \\
\hline grew up & $\begin{array}{l}\text { Outside of Pine Ridge } \\
\text { Reservation }\end{array}$ \\
\hline Familiarity of interviewee & Familiar \\
\hline $\begin{array}{l}\text { with Wind Cave National } \\
\text { Park }\end{array}$ & Unfamiliar \\
\hline The last time interviewee & Recently \\
\hline visited the National Park & A long time ago \\
\hline & Never visited \\
\hline Frequency that interviewee & Often \\
\hline visits park & Seldom \\
\hline The significance of Wind & Site of the Emergence Story \\
\hline Cave to the interviewee & Sacred/holy site \\
\hline & No significance \\
\hline Thoughts or feelings of & Positive \\
\hline $\begin{array}{l}\text { interviewee toward Wind } \\
\text { Cave National Park }\end{array}$ & Negative \\
\hline Whether or not interviewee & Has been on a cave tour \\
\hline $\begin{array}{l}\text { has been on an NPS ranger- } \\
\text { led cave tour of Wind Cave }\end{array}$ & Has not been on a cave tour \\
\hline Thoughts or feelings of & Positive \\
\hline interviewee about Cave & Negative \\
\hline Tour & Has not been on cave tour \\
\hline $\begin{array}{l}\text { Whether or not the } \\
\text { interviewee has seen the } \\
\text { Visitor Center, viewed }\end{array}$ & $\begin{array}{l}\text { Has experienced these non- } \\
\text { personal interpretive } \\
\text { elements }\end{array}$ \\
\hline $\begin{array}{l}\text { exhibits, and/or seen } \\
\text { interpretive signage at Wind } \\
\text { Cave National Park }\end{array}$ & $\begin{array}{l}\text { Has not experienced these } \\
\text { non-personal interpretive } \\
\text { elements }\end{array}$ \\
\hline \begin{tabular}{|l} 
Thoughts or feelings of the \\
\end{tabular} & Positive \\
\hline $\begin{array}{l}\text { interviewee about the } \\
\text { Visitor Center, its exhibits, } \\
\text { and/or interpretive signage } \\
\text { at Wind Cave National Park }\end{array}$ & Negative \\
\hline
\end{tabular}




\begin{tabular}{|l|l|}
\hline Feelings of the interviewee & Positive \\
\cline { 2 - 2 } $\begin{array}{l}\text { about non-Lakota people } \\
\text { entering Wind Cave }\end{array}$ & Negative \\
\cline { 2 - 2 } & Indifferent \\
\hline
\end{tabular}

Other more specific child codes were developed during coding process. 


\section{References}

Afraid of Bear-Cook, L. (2009, August 24). Pine Ridge Indian Reservation community \& district hearings to appoint representatives of the Oglala Sioux Tribe to meet with President Barack Obama on Black Hills land claim issues and reaffirm that the Black Hills are not for sale, following an historic gathering of Oglala Lakota Nation. Lakota Country Times. Retrieved from www.lakotacountrytimes.com/news/2009-09-01/ local_news/008.html.

Albers, P. C. (2003). The home of the bison: An ethnographic and ethnohistorical study of traditional cultural affiliations to Wind Cave National Park. Minneapolis-St. Paul, MN: University of Minnesota.

Allendorf, T. D. (1999). Local residents' perceptions of protected areas in Nepal: beyond conflicts and economics. PhD thesis. University of Minnesota, St. Paul, 98 p.

American Indian Humanitarian Foundation. (2014) Pine Ridge Statistics [Web]. Retrieved from www.4aihf.org/id40.html.

American Indian Religious Freedom Act of 1978, 42 U.S.C.A. $§ 1996$ (1996).

Anthony, B. (2007). The dual nature of parks: attitudes of neighbouring communities towards Kruger National Park, South Africa. Environmental Conservation 34(3), 236-245.

Arnberger, A., \& Brandenburg, C. (2007). Past on-site experience, crowding perceptions, and use displacement of visitor groups to a peri-urban national park. Environmental Management 40(1), 34.

Associated Press. (1973, March 27). Marshal wounded. Spokane Daily Chronicle, p. 2.

Atleo, M. (1998, September). The role of sacred sites in the embodiment of the territories of Nuu-chah-nulth First Nations. Poster presented at UNESCO Sacred Sites Symposium, Paris, France.

Baral, N. \& Heinen, J. T. (2007). Resources use, conservation attitudes, management intervention and park-people relations in Western Terai landscape of Nepal. Environmental Conservation 34(1), 64-72.

Beltrán, J. (Ed.) (2000). Indigenous and traditional peoples and protected areas: Principles, guidelines and case studies. Gland, Switzerland: IUCN/WWF International.

Bhuju, U. R., Shakya, P. R., Basnet, T. B., \& Shrestha, S. (2007). Nepal biodiversity resource book. Protected areas, Ramsar sites, and World Heritage Sites. Kathmandu, Nepal: International Centre for Integrated Mountain Development.

Biernacki, P., \& Waldorf, D. (1981). Snowball sampling: problems and techniques of chain referral sampling. Sociological Research and Methods 10(2), 141-163. 
Blackburn, T. C. \& Anderson, K. (Ed.) (1993). Before the wilderness: Environmental management by native Californians. Menlo Park, CA: Ballena Press.

Branch, T. (2006). At Canaan's Edge: America in the King years 1965-1968. New York, NY: Simon \& Schuster.

Brokaw, C. (2009, April 21). Lawsuit would let Sioux take money for Black Hills. Rapid City Journal. Retrieved from rapidcityjournal.com/news/local/top-stories/lawsuit-wouldlet-sioux-take-money-for-black-hills/article_a062dee8-6792-5710-91b6b8cba0457f3d.html.

Brown, G. and Weber, D. (2011). Public participation GIS: A new method for national park planning. Landscape and Urban Planning 102(1), 1-15.

Browne, K. (2005). Snowball sampling: using social networks to research non-heterosexual women. International Journal of Social Research Methodology 8(1), 47-60.

Burby, R. J. (2003). Making plans that matter: Citizen involvement in government action. Journal of the American Planning Association 69(1), 33-47.

Burns, K. \& Duncan, D. (Producers), \& Burns, K. (Director). (2009). The National Parks: America's Best Idea [Motion Picture]. United States: Public Broadcasting Service.

Canby, Jr., W. C. (2015). American Indian Law, 6th Ed. Saint Paul, MN: West Publishing Company.

Cherokee Nation v. Georgia, 30 U.S. (1831).

Claymore, E. (2010, July 9). Gerard Baker, top Indian official at NPS, retires. Native Sun News. Retrieved from http://www.nathpo.org/News/Federal/NewsFederal_Agencies75.htm.

Cook, A. J. (2014, December 3). Tribes buy final piece of Pe'Sla. Rapid City Journal. Retrieved from rapidcityjournal.com/news/local/tribes-buy-final-piece-of-pe-sla/ article_7b584d77-d2a0-5184-98c5-81396f76bc4e.html.

De Boer, W. F. \& Baquete, D. S. (1998). Natural resource use, crop damage and attitudes of rural people in the vicinity of the Maputo Elephant Reserve, Mozambique. Environmental Conservation 25(3), 208-218.

Dustin, D. L., Schneider, I. E., McAvoy, L. H., \& Frakt, A. N. (2002). Cross cultural claims on Devils Tower National Monument: A case study. Leisure Sciences 24(1), 79-88.

Eagley, A. H. \& Chaiken, S. (1993). The psychology of attitudes. Fort Worth, TX: Harcourt, Brace, Jovanovich. 
Erikson, E. (1950). Childhood and society. New York, NY: Norton.

Erikson, E. (Ed.) (1963). Youth: Change and challenge. New York, NY: Basic Books.

Exec. Order No. 13,007, 61 C.F.R. 26,771 (1996).

Executive Order No. 13,647, 3 C.F.R. 311-314 (2013).

Federal Preservation Institute. (n.d.). Consultation with Native Americans: A historic preservation responsibility. Retrieved from http://www.achp.gov/docs/nafolder.pdf.

Feinstein, C. H. (2005). An economic history of South Africa: Conquest, discrimination, and development. Cambridge, U.K.: Cambridge University Press.

Fernández-Baca, J. C., \& Martin, A. S. (2007). Indigenous peoples and protected areas management innovations in conservation series, parks in peril program. Arlington, VA: The Nature Conservancy.

Fisher, R. (1994). Contact and conflict: Indian-European relations in British Columbia 17741890. Vancouver, BC, Canada: University of British Columbia Press.

Funada-Classen, S. (2013). The origins of war in Mozambique. A history of unity and division. Somerset West, South Africa: African Minds.

Gillingham, S. \& Lee, P. C. (1999). The impact of wildlife-related benefits on the conservation attitudes of local people around the Selous Game Reserve, Tanzania. Environmental Conservation 26(3), 218-228.

Goodman, L. A. (1961). Snowball sampling. The Annals of Mathematical Statistics 32(1), 148-170.

Ham, S. H. (1992). Environmental interpretation: a practical guide. Golden, CO:

Fulcrum Press.

Heinen, J. T. (1993). Park-people relations in Kosi-Tappu Wildlife Reserve, Nepal: a socio-economic analysis. Environmental Conservation 20(1), 25-34.

Holmes, N. C., Blotkamp, A., Lackey, B., Hollenhorst, S. J. (2011). Wind Cave National Park visitor study: summer 2010. Natural Resource Report NPS/NRPC/SSD/NRR2011/108/106477. Fort Collins, Colorado: National Park Service.

Infield, M. (1988). Attitudes of a rural community towards conservation and a local conservation area in Natal, South Africa. Biological Conservation 45(1988), 21-46.

Infield, M. \& Namara, A. (2001). Community attitudes and behaviour towards conservation: an assessment of a community conservation programme around Lake Mburo National Park, Uganda. Oryx 35(1), 48-60. 
International Labor Organization (ILO). (2003). ILO convention on indigenous and tribal peoples, 1989 (No. 169): A manual. Geneva, Switzerland: International Labour Office.

Johnson, M. G. (2009). Sioux: Warriors of the Plains. London, United Kingdom: Chartwell Books.

Johnson v. McIntosh, 21 U.S. (1823).

Kanyeihamba, G. W. (2010). Constitutional and political history of Uganda from 1894 to the present. Nairobi, Kenya: LawAfrica Publishers.

Kaus, A. (1993). Environmental perceptions and social relations in the Mapimí Biosphere Reserve. Conservation Biology 7(2), 398-406.

Keller, R. H. \& Turek, M. F. (1998). American Indians \& National Parks. Tucson, AZ: The University of Arizona Press.

King, M. A. (2007). Co-management or contracting?: Agreements between Native American tribes and the U.S. National Park Service pursuant to the 1994 Tribal Self-Governance Act. Harvard Environmental Law Review 31, 475-530.

Knapp, D., Volk, T., \& Hungerford, H. (1997). The identification of empirically derived goals for program development in environmental interpretation. The Journal of Environmental Education 28(3), 24-34.

Knudson, D. M., Cable, T. T., Beck, L. (1995). Interpretation of cultural and natural resources. State College, PA: Venture.

Lakota. (2005). In J. Mackenzie (Ed.), Cassell's peoples, nations and cultures. London, United Kingdom: Cassell.

Lavelle, J. P. (2001). Rescuing Paha Sapa: Achieving environmental justice by restoring the great grasslands and returning the sacred Black Hills to the Great Sioux Nation. Great Plains Natural Resources Journal 5(2001), 40.

Liu, L. (2016, September 13). Thousands of protesters are gathering in North Dakota-and it could lead to 'nationwide reform'. Retrieved from http://www.businessinsider.com/photos-north-dakota-pipeline-protest-2016-9/\#whilemembers-of-the-standing-rock-sioux-tribes-began-protesting-the-project-as-early-asapril-protests-heated-up-in-august-as-numbers-increased-to-the-thousands- 1 .

Lyng v. Northwest Indian Cemetery Protective Association, 485 U.S. 439 (1988).

Mabunda, D. M., \& Wilson, D. (2009). Commercialization of national parks: South Africa's Kruger National Park as an example. In J. Saarinen, F. Becker, H. Manwa, \& D. Wilson 
(Eds.), Sustainable tourism in southern Africa: Local communities and natural resources in transition (pp. 116-133). Bristol, United Kingdom: Channel View Publications.

Magnuson, S. (2010). The death of Raymond Yellow Thunder: And other true stories from the Nebraska-Pine Ridge border towns. Lubbock, TX: Texas Tech University Press.

Mahoney, M. (2011). This land is your land, this land is my land: An historical narrative of an intergenerational controversy over public use management of the San Francisco Peaks (master's thesis). Retrieved from https://repository.asu.edu/attachments/56997/content/Mahoney_asu_0010N_10960.pdf.

Manning, R. E., \& Lime, D. (1996). Crowding and carrying capacity in the national park system: Toward a social science research agenda. Crowding and congestion in the National Park System: Guidelines for management and research 86(1996), 27-65.

Marshall, M. N. (1996). Sampling for qualitative research. Family Practice 13(6), 522-525.

Matthiessen, P. (1992). In the spirit of Crazy Horse: The FBI's war against the American Indian Movement. New York, NY: Penguin Group.

Maxwell, L. A. (2013). Education in Indian country: Running in place. [Web]. Retrieved from www.edweek.org/ew/projects/2013/native-american-education/running-in-place.html.

Mbogoni, L. E. Y. (2013). Aspects of colonial Tanzania history. Dar es Salaam, Tanzania: Mkuki na Nyota Publishers.

McAvoy, L., McDonald, D., \& Carlson, M. (2003). American Indian/First Nation place attachment to park lands: The case of the Nuu-chah-nulth of British Columbia. Journal of Park and Recreation Administration 21(2), 84-104.

McCabe, B. (Producer). (2014). The battle of the greasy grass [Online video]. Retrieved from http://www.smithsonianmag.com/videos/category/history/the-battle-of-the-greasygrass/?no-ist.

McLean, J. \& Straede, S. (2003). Conservation, relocation, and the paradigms of park and people management - a case study of Padampur villages and the Royal Chitwan National Park, Nepal. Society and Natural Resources 16(6), 509-526.

McNeely, J. (1993). Afterward. People and protected areas: Partners in prosperity. In E. Kemf (Ed.), The law of the mother: Protecting indigenous peoples in protected areas. San Francisco, CA: Sierra Club/Random House.

Means, M. (1996). Where white men fear to tread: The autobiography of Russell Means. London, U.K.: Macmillan. 
Mehta, J. N. \& Heinen, J. T. (2001). Does community-based conservation shape favorable attitudes among locals? an empirical study from Nepal. Environmental Management 28(2), 165-177.

Morrison, S. (2014). In kind or monetary restitution: Historic wrongs and indigenous land claims. Journal of Politics and Law 7(2), 50-62.

National Park Service. (2011). Addition of historic ranch to Wind Cave National Park [press release]. Retrieved from www.nps.gov/wica/learn/news/addition-of-historicranch-to-wind-cave-national.park.html.

National Park Service (2015). Cultural resources program manager [Web]. Retrieved from www.nps.gov/training/RSC/CRMSPEC.REV.doc.

National Park Service (2015). History \& culture [Web]. Retrieved from www.nps.gov/ wica/learn/historyculture/index.htm.

National Park Service (2015). National Park System [Web]. Retrieved from www.nps.gov/aboutus/news/upload/CLASSLST-409-updated-12-17-2015.pdf.

National Park Service (2015). Speleothems - boxwork [Web]. Retrieved from www.nps.gov/wica/learn/nature/speleothems-boxwork.htm.

National Park Service. (2015). Visitor guide: park information and maps. Hot Springs, South Dakota: United States Department of the Interior.

National Park Service. (2017). Artist in residence program. Retrieved from https://www.nps.gov/agfo/getinvolved/supportyourpark/artist-in-residence-program.htm.

National Park Service. (2017). Frequently asked questions. Retrieved from https://www.nps.gov/deto/faqs.htm.

National Park Service. (2017). History and culture. Retreived from https://www.nps.gov/cach/learn/historyculture/index.htm.

New York Times, The. (1991, November 27). Custer falls again as site is renamed. The New York Times, retrieved from http://www.nytimes.com/1991/11/27/us/custer-falls-again-assite-is-renamed.html.

New York Times Company, The. (1982, September 27). Tension rises in wake of death at Sioux camp. The New York Times. Retrieved from www.nytimes.com/1982/09/27/us/ tension-rises-in-wake-of-death-at-sioux-camp.html.

Nishi, J. S., Shury, T., \& Elkin, B. T. (2006). Wildlife reservoirs for bovine tuberculosis (Mycobacterium bovis) in Canada: Strategies for management and research. Veterinary Microbiology 112(2006), 325-338. 
Noy, C. (2008). Sampling knowledge: The hermeneutics of snowball sampling in qualitative research. International Journal of Social Research Methodology 11(4), 327-344.

Nucci, L. P., \& Gingo, M. (2011). The development of moral reasoning. In U. Goswami (Ed.), The Wiley-Blackwell handbook of childhood cognitive development, $2^{\text {nd }}$ ed ( $\left.\mathrm{pp} 420-444\right)$. Wiley-Blackwell.

Obama, B. (2009). Memorandum for the Heads of Executive Departments and Agencies, Subject: Tribal Consultation.

Oglala Sioux Tribe. (2015). Oglala Sioux Tribe Enrollment Office [Web]. Retrieved from www.oglalalakotanation.org/enrollment.html.

Olsen, B. (2008). Sacred places, North America: 108 destinations. San Francisco, CA: CCC Publishing.

Ostler, J. (2010). The Lakotas and the Black Hills. London, United Kingdom: Penguin Books.

Palinkas, L. A., Horwitz, S. M., Green, C. A., Wisdom, J. P., Duan, N., \& Hoagwood, K. (2015). Purposeful sampling for qualitative data collection and analysis in mixed method implementation research. Administration and Policy in Mental Health and Mental Health Services Research 42(5), 533-544.

Parks Canada. (2016). Best practices and lessons learned in indigenous engagement. Retrieved from http://www.pc.gc.ca/eng/agen/aa/te-wt/introduction.aspx.

Plas, J. M. \& Bellet, W. (1983). Assessment of the value-attitude orientations of American Indian Children. Journal of School Psychology 21(1), 57-64.

Prashant, J. (2014). Battles of the new republic: A contemporary history of Nepal. London, United Kingdom: Hurst \& Company.

Record, I. (Producer and Director). (2012). Return of the Red Lake Walleye [Motion picture]. United States: (Available from Vision Maker Media, 1800 N $33^{\text {rd }}$ Street, Lincoln, NE 68503-1409.

Red Lake Band of Chippewa Indians v. Swimmer, 740 F. Supp. 9 (D.D.C. 1990).

Reinhardt, A. D. (2015). Welcome to the Oglala Nation: a documentary reader in Oglala Lakota political history. Retrieved from site.ebrary.com.www.libproxy.wvu.edu/ liblnwvu/detail.action?docID=11081698.

Religious Freedom Restoration Act of 1993, 42 U.S.C.A. § 2000 bb et seq. (2000). 
Rights and Resources Initiative. (2015). Protected areas and the land rights of indigenous peoples and local communities: current issues and future agenda. Washington, D.C.: Rights and Resources Initiative.

Roldán, O. R. (2004). Models for recognizing indigenous land rights in Latin America. Washington, D.C.: The World Bank Environmental Department.

Runte, A. (1997). National parks: The American experience. Lincoln, NE: University of Nebraska Press.

Sadler, G. R., Lee, H., Lim, R. S., \& Fullerton, J. (2010). Recruiting hard-to-reach United States population sub-groups via adaptations of snowball sampling strategy. Nursing \& Health Sciences 12(3), 369-374.

Secretariat of the Convention on Biological Diversity-SCBD. (2004). Program of work on protected areas (CBD work programs). Montreal, Canada: Secretariat of the Convention on Biological Diversity.

Sioux Nation of Indians, et al. v. United States, 601 F.2d (Ct. Cl. 1979).

Smetana, J. G., Robinson, J., \& Rote, W. M. (2015). Socialization in adolescence. In J. E. Grusec \& P. D. Hastings (Eds.), Handbook of socialization: Theory and research, $2^{\text {nd }}$ ed (pp. 60-84). New York, NY: Guildford Press.

South Dakota Department of Tribal Relations. (2011). Oglala Sioux Tribe [Web]. Retrieved from www.sdtribalrelations.com/oglala.aspx.

Spence, M. D. (2011). Passages through many worlds: historic resource study of Wind Cave National Park [Web]. Retrieved from www.nps.gov/wica/learn/historyculture/ upload/ WICA_HRS-2.pdf

Stasiuk, D. D. (2012). Contestation of place: Bear Butte and the Sturgis motorcycle rally. M.A. Thesis. Kent State University, Kent, 112 p.

Steelman, T. A. (2001). Elite and participatory policymaking: Finding balance in a case of national forest planning. Policy Studies Journal 29(1), 71-89.

Stevens, S. (Ed.). (1997). Conservation through cultural survival: Indigenous peoples and protected areas. Washington, D.C.: Island Press.

Strauss, V. (2015). Latest high school graduation rates - state by state. [Web]. Retrieved from https://www.washingtonpost.com/news/answer-sheet/wp/2015/02/12/latest-high- schoolgraduation-rates-state-by-state/.

Sundstrom, L. (1996). Mirror of heaven: Cross-cultural transference of the sacred geography of the Black Hills. World Archeology 28(2), 177-189. 
Taylor, P. A., Grandjean, B. G., \& Gramann, J. H. (2011). National Park Service comprehensive survey of the American public, 2008-2009: Racial and ethnic diversity of National Park System visitors and non-visitors. Natural Resource Report NPS/NRSS/SSD/NRR—2011432. National Park Service, Fort Collins, Colorado.

Tilden, F. (1957). Interpreting our heritage. Chapel Hill, NC: University of North Carolina.

Turiel, E. (2010). The development of morality: Reasoning, emotions, and resistance. In W. F. Overton \& R. M. Lerner (Eds.), The handbook of life-span development, Vol 1: Cognition, biology, and methods (pp. 554-583). Hoboken, NJ: John Willey \& Sons Inc.

Turner III, D. W. (2010). Qualitative interview design: A practical guide for novice investigators. The Qualitative Report 15(3), 754-760.

Tuxill, J. L., Mitchell, N. J., \& Clark, D. (2009). Stronger together: A manual on the principles and practices of civic engagement. Woodstock, VT: Conservation Study Institute.

United Nations Educational, Scientific and Cultural Organization (UNESCO). (2016). Wood Buffalo National Park [Web]. Retrieved from whc.unesco.org/en/list/256.

United States v. Lara, 541 U.S. (2004)

United States v. Sioux Nation of Indians, 448 U.S. (1980).

United States Census Bureau. (2015). American Fact Finder [Web]. Retrieved from factfinder.census.gov/faces/nav/jsf/pages/index.xhtml.

United States Department of the Interior (2005). 2005 American Indian population and labor force report [Web]. Retrieved from www.sdtribalrelations.com/new/ tribalstatprofiles/oststatprofile2011.pdf.

U.S. Const. amend. I.

Van Ness Feldman LLC. (2017). Environment-National Parks and federal land concessions. Retrieved from http://www.vnf.com/national-parks-and-federal-land-concessions.

Vander Stoep, G. A. (1991). Interpretation: a resource and curricula guide for the United States and Canada. Ft. Collins, CO: National Association for Interpretation.

Wagar, J. A. (1964). The carrying capacity of wild lands for recreation. Forest Science 10(3), $1-24$.

West, K. (1991). Joint management of Canada's northern national parks. In West, P. C. \& Brechin, S. R. (Eds.) Resident peoples and national parks. Social dilemmas and strategies in international conservation. Tucson, AZ: University of Arizona Press. 
Whisnant, A. M., Miller, M. R., Nash, G. B., \& Thelen, D. (2011). Imperiled promise: The state of history in the National Park Service. Bloomington, IN: Organization of American Historians.

Wilderness.net. (n.d.). Kachina Peaks Wilderness. Retrieved from http://www.wilderness.net/index.cfm?fuse=NWPS\&sec=wildView\&wname $=$ Kachina\%2 OPeaks.

Winer, N. (2003). Co-management of protected areas, the oil and gas industry and indige-nous empowerment - the experience of Bolivia's Kaa Iya del Gran Chaco. Section I: The complexities of governing protected areas, 181 .

Winslow, L. (Producer). (2011, August 24). PBS Newshour [Television broadcast]. Arlington, VA: Public Broadcasting Service.

World Health Organization. (2015). Global health observatory data repository: life expectancy - data by country [Web]. Retrieved from apps.who.int/gho/data/node.main.688? lang=en.

Worcester v. Georgia, 31 U.S. (1832).

Worster, D. (1992). Under western skies: Nature and history in the American West. Oxford, England, U. K.: Oxford University Press. 